$1-1-1959$

\title{
Characteristics of livestock slaughter plants in northeastern United States
}

Kenneth D. McIntosh

Follow this and additional works at: https://researchrepository.wvu.edu/ wv_agricultural_and_forestry_experiment_station_bulletins

\section{Digital Commons Citation}

McIntosh, Kenneth D., "Characteristics of livestock slaughter plants in northeastern United States" (1959). West Virginia Agricultural and Forestry Experiment Station Bulletins. 428.

https://researchrepository.wvu.edu/wv_agricultural_and_forestry_experiment_station_bulletins/406 @ WVU. It has been accepted for inclusion in West Virginia Agricultural and Forestry Experiment Station Bulletins by an authorized administrator of The Research Repository @WVU. For more information, please contact ian.harmon@mail.wvu.edu. 


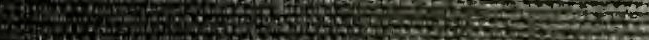

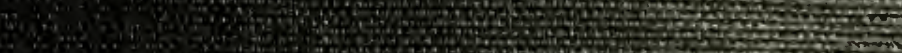
S.

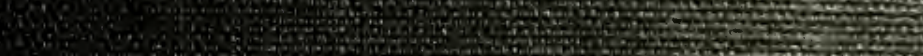
4.6.

(1)

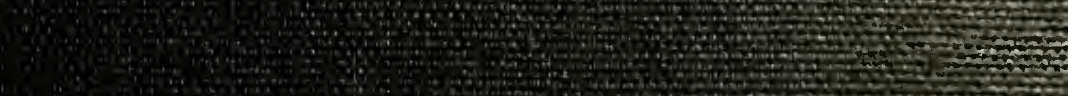

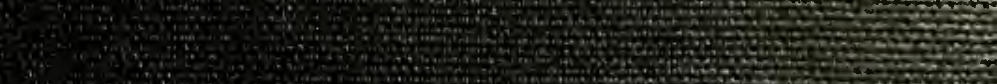

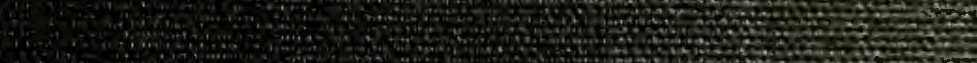
8 a

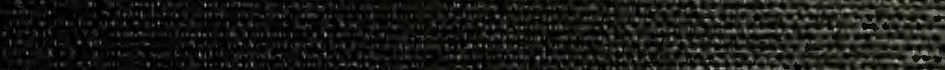

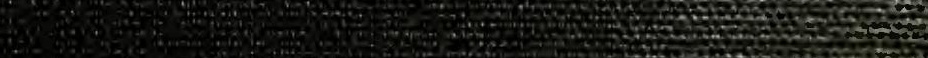

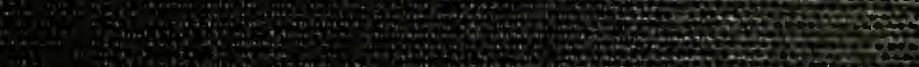
7.5. 19.5.

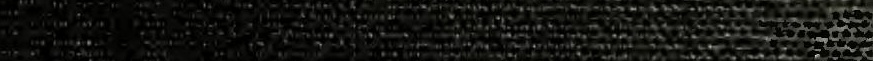

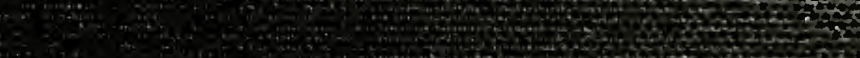

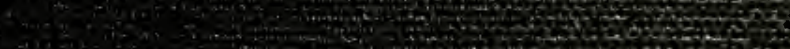
i.

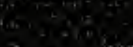

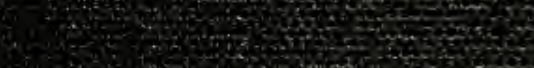
(3) ic 4 ,

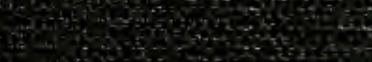
(2. 3 .

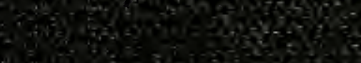

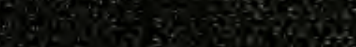

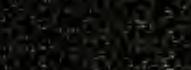
tores?

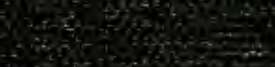
Monste

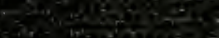
ing

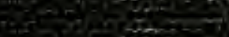
r.t.

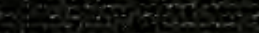

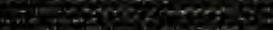

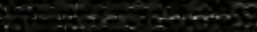

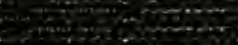

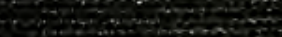

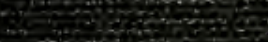
स:

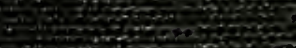

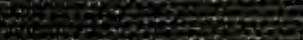
Now

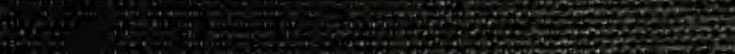

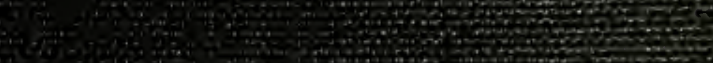

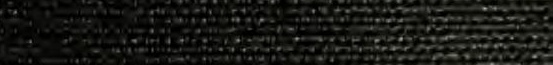
Hind

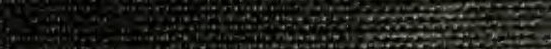
(1)

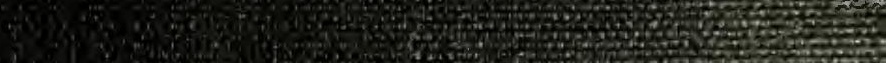

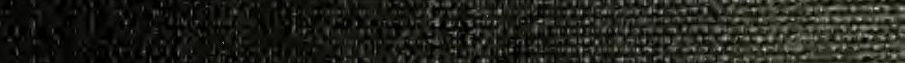
10. 
Digitized by the Internet Archive in 2010 with funding from

Lyrasis Members and Sloan Foundation 
Characteristics of

LINESTOCK SLAUGHTER PLANTS

in Northeastern United States

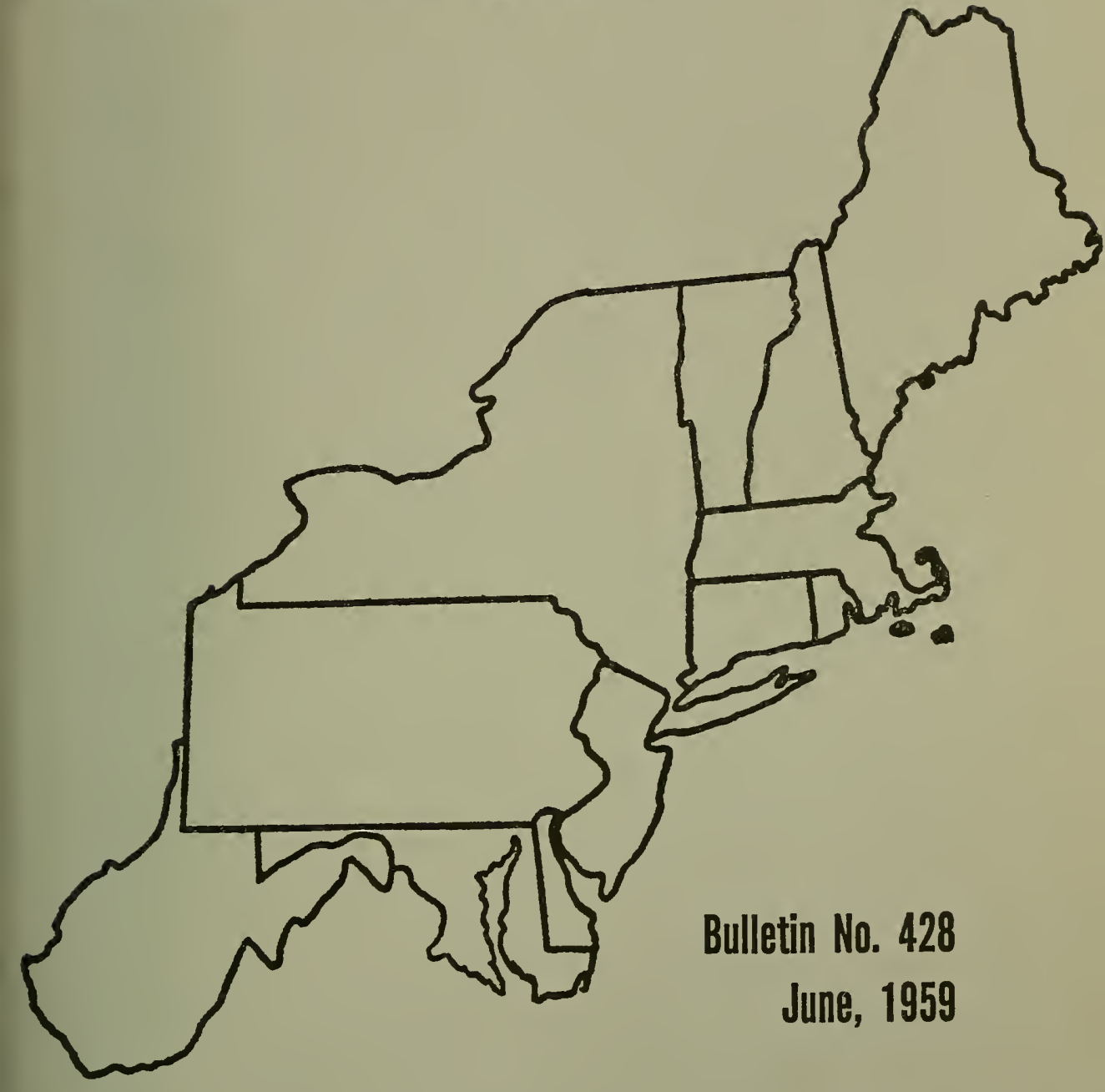

WEST VIRGINIA UNIVERSITY AGRICULTURAL EXPERIMENT STATION 



\title{
Characteristics of
}

\section{LIVESTOCK SLAUGHTER PLANTS in Northeastern United States}

\author{
by \\ Kenneth D. Mclntosh
}

WEST VIRGINA UNIVERSITY AGRICULTURAL EXPERIMENT STATION 


\section{West Virginia UNiversity}

Agricultural Exíkiment Station

Collfge of Agricllture, forestri, and Home Economics

A. H. Vanlandingham, Diregtor

MORGANTOWN 


\section{Foreword}

IN 1954, representatives from the agricultural experiment stations in the Northeast, together with officials from the United States Department of Agriculture, initiated a regional livestock marketing study. The project was entitled "Marketing Procedures and Outlets for Northeastern Livestock with Emphasis on Dairy Animals," and the primary objective was to find ways to improve the efficiency of livestock marketing.

The project was broken down into four separate study phases; producers, dealers, auctions, and slaughter plants. Each of these was extensively surveyed; and publications of the analysis of data from auctions and dealers were prepared and distributed. ${ }^{1}$

This report is an analysis of the data obtained from slaughter plants. The Cooperating agencies are:

State Agricultural Experiment Stations
Connecticut ${ }^{2}$
Delaware $^{2}$
Maine
Maryland
Massachusetts
New Hampshire ${ }^{2}$
New Jersey
New York
Pennsylvania
Rhode Island
Vermont
West Virginia

United States Department of Agriculture

Agricultural Marketing Service

Farmer Cooperative Service

State Experiment Stations Division

Regional Coordinator

${ }^{1}$ RandelI, C. G., Livestock Auctions in the Northeastern States. Farmer Cooperative Service Bulletin No. 8, Northeast Regional Publication No. 26. Also Merohant, C. H., Livestock Deuters' Operutio:zs. Maine Bulletin No. 555, Northeast Regional Publication No. 36. 'These states did not actively participate in this study of slaughter plants. 


\section{THE AUTHOR}

Kenneth D. McIntosh, author of Characteristics of Livestock Slaughter Plants in Northeastern United States, is Assistant Agricultural Economist in the West Virginia University Agricultural Experiment Station and Regional Coordinator, Northeastern Livestock Marketing Technical Committee. 


\section{Summary}

THE results of a 1955 sample survey of livestock slaughter plants in Northeastern United States indicate that 46 per cent of the cattle, 18 per cent of the calves, 84 per cent of the hogs and 92 per cent of the sheep and lambs slaughtered in these plants were obtained outside of the region. Of the cattle some 70 per cent of the beef steers and heifers, 38 per cent of the bulls and 7 per cent of the dairy cattle were procured in other regions. Plant operators stated they procured livestock in other regions because there was a "wider selection" of "quality animals" in "sufficient quantities" and at "favorable prices."

Procurements within the Northeastern region consisted largely of cull dairy animals and calves. These "by-products" of the dairy industry, together with other meat animals marketed in the region, were obtained primarily at terminal and auction markets. These two sources accounted for well over two thirds of all meat animals purchased in the Northeastern region. Auction markets were most important as a source of dairy cattle and calves, while terminal markets were most important as a source of lambs, hogs, beef steers and heifers.

During 1955 these plants sold most of their meat and meat products to retail outlets. The second ranking outlet used was jobbers and wholesalers. Together these two sales outlets accounted for 75 per cent of the beef, 79 per cent of the veal, 61 per cent of the pork and 95 per cent of lamb. Sales to meat processors ranked third, accounting for 12 per cent of the beef, 14 per cent of the veal and 9 per cent of the pork.

A large majority of all meat except pork was sold as whole, half, or quarter carcasses. During 1955, 60 per cent of the beef, 87 per cent of the veal, 8 per cent of the pork and 98 per cent of the lamb was sold in this form. Approximately 70 per cent of the pork was sold as wholesale cuts, either fresh or cured. Boned meat was the second ranking form in which meat was sold, accounting for about 14 per cent of the beef and 6 per cent of the veal. Most of the boned meat came from cull dairy cattle and bulls.

Federal grading of meat was performed almost exclusively in federally inspected plants. None of the local slaughterers sold federally graded meat, while only 5 per cent of the meat sold by wholesale slaughterers was federally graded. About 34 per cent of the beef, 10 per cent of the pork, 9 per cent of the lamb and 7 per cent of the veal originating in Northeastern slaughter plants was federally graded. Practically all of the graded beef came from beef steers and heifers. 
The size of plant, as measured in number of head slaughtered, varied greatly among plants in each classification and among plants in different classifications. For instance, in federally inspected plants slaughtering cattle, calves, sheep and lambs the range in numbers slaughtered per plant was 2,500 to 78,000 head of cattle, 500 to 74,000 head of calves, and 300 to 245,000 head of sheep and lambs. The plant operators indicated that insufficient refrigeration space, lack of skilled labor and other internal plant problems were the most important factors limiting their operations.

A large majority of these plants were located near or within large population centers. Practically ail of the plants operated 52 weeks during 1955 and most of them were inspected by either governmental or religious authorities.

Federally inspected plants were the most important class of plants, accounting for 74 per cent of the beef, 42 per cent of the veal, 82 per cent of the pork and 88 per cent of the lamb sold by all plants. Wholesale plants ranked second and were responsible for 20 per cent of the beef, 42 per cent of the veal, 16 per cent of the pork, and 9 per cent of the lamb. Local plants ranked third and accounted for 6 per cent of the beef, 17 per cent of the veal, 2 per cent of the pork and 3 per cent of the lamb. 


\section{Contents}

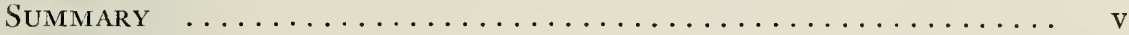

INTRODUCTION $\ldots \ldots \ldots \ldots \ldots \ldots \ldots \ldots \ldots \ldots \ldots \ldots \ldots \ldots \ldots \ldots \ldots \ldots \ldots \ldots$

General Characteristics of Livestock and Meat Production

in the Northeastern Region .................. 2

General Characteristigs of Slaughtering Plants in the

Northeastern Region .................... 3

Selection and Location of Sample Slaughter Plants . . . . . . . 6

Type of Inspection and Operating Period of Northeastern

Slaughter Plants $\ldots \ldots \ldots \ldots \ldots \ldots \ldots \ldots \ldots \ldots \ldots \ldots \ldots \ldots \ldots$

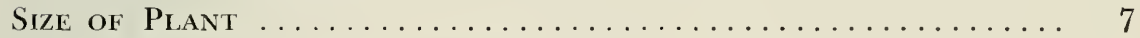

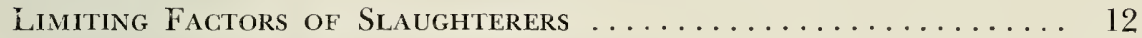

Livestock Procured from Other Regions .............. 14

Amiount and Sources of Livestock Procured Within the

Northeastern Region ..................... 16

Sales Outlets Used for Distributing Meat and Meat Products . 18

The Proportion of Meat Sold in Different Forms of

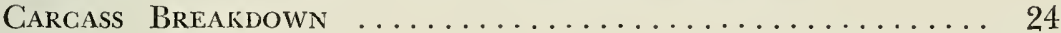

Federally-Graded Meat . . . . . . . . . . . . . . 27

Disposition of Livestock By-Products . . . . . . . . . . . 29

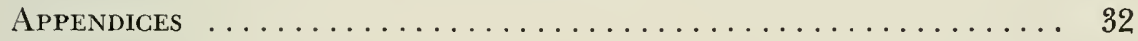





\section{Characteristics of Livestock Slaughter Plants in Northeastern United States}

KENNETH D. MCINTOSH

\section{Introduction}

0 URING the past twenty years, considerable clata have been assembled concerning the marketing agencies through which livestock slaughterers obtain their slaughter animals. There has also been a considerable accumulation of knowledge pertaining to the movement of meat and meat products from slaughter plants to retail stores, restaurants, hotels, jobbers, wholesalers, and others.

Some of the publications resulting from marketing studies were rather broad analyses for the entire United States, while others were quite specific for some state or group of states. Although the Northeastern region was included in several of the more general analyses, very little specific data have been published concerning the agencies used by slaughterers in obtaining slaughter animals and the markets to which they sell their meat and meat products in this region.

Over a period of time, the relative importance of agencies patronized by slaughterers changes quite significantly. Witness the growth of auctions, "drect" marketing, large-scale feed lot operations, frozen meat concerns, and freezer-locker trade in the past twenty years.

The changing nature of the marketing channels requires that from time to time a reassessment be made of the marketing agencies. This is done to keep abreast of changes in market patterns, to acquaint new workers and others with the field of livestock marketing, to obtain preparatory material for more advanced research, and to aid in making livestock marketing decisions.

In 1954, farmers in the Northeastern region sold 5.1 million head of livestock for $\$ 277,247,000,9$ per cent of their cash income:" While the majority of these animals were cull dairy animals and calves representing secondary sources of incone to many farmers, the total value added to farm income through the sale of livestock was considered important enough to warrant a study of the marketing procedures and outlets for Northeastern livestock. To facilitate the study, it was broken down into four parts: a producer survey, a dealer survey, an auction survey, and a slaughter plant survey.

${ }^{3}$ Randell. C. G., Lirestoek Auetions in the Northerstern States. op. eit.. p. 1. 
This is the report on slaughter plants and is largely a descriptivetype analysis of the federally inspected, wholesale, and local slaughtering establishments. ${ }^{+}$During 1955, surveys were made of all three classes of plants to determine the sources of slaughter livestock and the sales outlets used to distribute meat and meat products. The report which follows is based on the sample results ${ }^{5}$ and the primary objectives of the report are to indicate:

1. The sources of slaughter animals and the relative importance of each.

2. The distribution channels used by Northeastern slaughterers to dispose of their meat and meat products.

3. The proportion of meat sold as whole, half, or quarter carcasses, wholesale cuts, boneless beef, consumer ready (retail cuts), processed meats, lard, tallow and other breakdowns.

Although other information was gathered and is presented, these three objectives are considered to be of major importance.

\section{General Characteristics of Livestock and Meat Production in The Northeastern Region}

Dairy animals are the principal type of livestock produced in the Northeast. West Virginia is the only state in the Northeast which produces cattle and calves primarily for meat, although Maryland, Pennsylvania, and New York also produce a considerable number of meat animals. ${ }^{6}$ Although the chief function of dairy animals is milk production, the sale of calves and cull dairy animals is an important secondary source of income to dairy farmers and can be the difference between profit and loss.

The livestock inventory in January, 1958 indicates that in seven of the 12 Northeastern states animals kept for milk account for over 90 per cent of the cattle and calves. ${ }^{\top}$ In four other states well over 70 per cent of the cattle and calves are kept for milk. For the entire region

${ }^{4}$ These plant classificatious are from Number of Liveslock Slanghter Establishments, Nareh 1, 1955, a United States Department of Agriculture publication dated June 15, 1955. According to USDA classifications, federally inspected slaughter plants are those which slaughter livestock under inspection conducted by the Meat Inspection Branch of the USDA. Wholesale and local slaughtering plants not under federal inspection are classified on the basis of volume handled per year. Wholesale plants are those whose anuual slaughter is more than $2,000,000$ pounds live weight, while local plants are those whose annual slaughter is less than $2,000,000$ pounds, but more than 300,000 pounds live weight.

${ }^{5}$ For sampling procedure, see Appendix A.

${ }^{6}$ Livestock and Poultry Inventory, Jan. 1. Number, Talue, and Classes. TSDA, AMS, Crop Reporting Board, 1eh. 14, 1958.

${ }^{7} I b i a$. 
swine, sheep and lanb production is relatively insignificant, but in certain areas, especially in West Virginia, Pennsylvania, Maryland and New York, these animals are of considerable importance as sources of income.

Livestock production in the Northeast is not sufficient to meet the demand for meat in the area. This is especially true for the higher quality cuts, such as beef steaks and roasts, pork loins and hams, leg of lamb and lamb chops. With pork and lamb production at relatively insignificant levels and dairy animals not possessing those necessary attributes for quality meat production, considerable quantities of the meat consumed in the region must be imported. It has been stated that roughly two thirds of the meat is produced west of the Mississippi River and two thirds consumed east of the Mississippi River.

Although dairy animals do not provide the quality meat that consumers demand in primal beef cuts, they do provide large amounts of beef which is used for hamburgers, stewing meats, sauages, loaves, and other processed meats. At the same time, these animals furnish an annual crop of calves that are used in satisfying the demand for veal. At times the importance of dairy animals as a source of beef and veal is overlooked. It has been estimated that roughly 35 per cent of our beef and veal supply comes from dairy cattle. ${ }^{9}$ A dependency as large as this certainly cannot be ignored.

\section{General Characteristics of Slaughtering Plants in the The Northeastern Region}

There were about 700 slaughtering establishments operating in the Northeast in 1955..$^{10}$ These plants are generally located near large population centers and range in size from small one-man operations to giant corporations employing several thousand employees. Figure 1 shows the locations of the slaughter plants in the sample. Mainly for definitive purposes, slaughter plants are classified as federally inspected, wholesale, and local slaughter establishments. For definitions of these plant classifications, see footnote 4 .

In general, federally inspected plants slaughter, process, and distribute more livestock and meat than do wholesale or local slaughtering establishments. These plants are more specialized than wholesale or local plants with over 70 per cent of the plants killing either one or two kinds of meat animals (Table 1). Federally inspected plants also have a more extensive supply system than either wholesale or local plants, reaching out to the Midwest and North Central regions for a large share of their

sFowler, Stewart H., The Warlieting of Livestock and Meat. Interstate Printers and Publishers, Inc., Danville, I11., 1957. p. 29.

${ }^{9} I$ bid., p. 41.

${ }^{10} \mathrm{Number}$ of Livestock Slaughler Establishments, op. cit. 
- Local Slaughter Plants

O Wholesale Slaughter Plants Slaughter Plants

$\triangle$ Federally Inspected

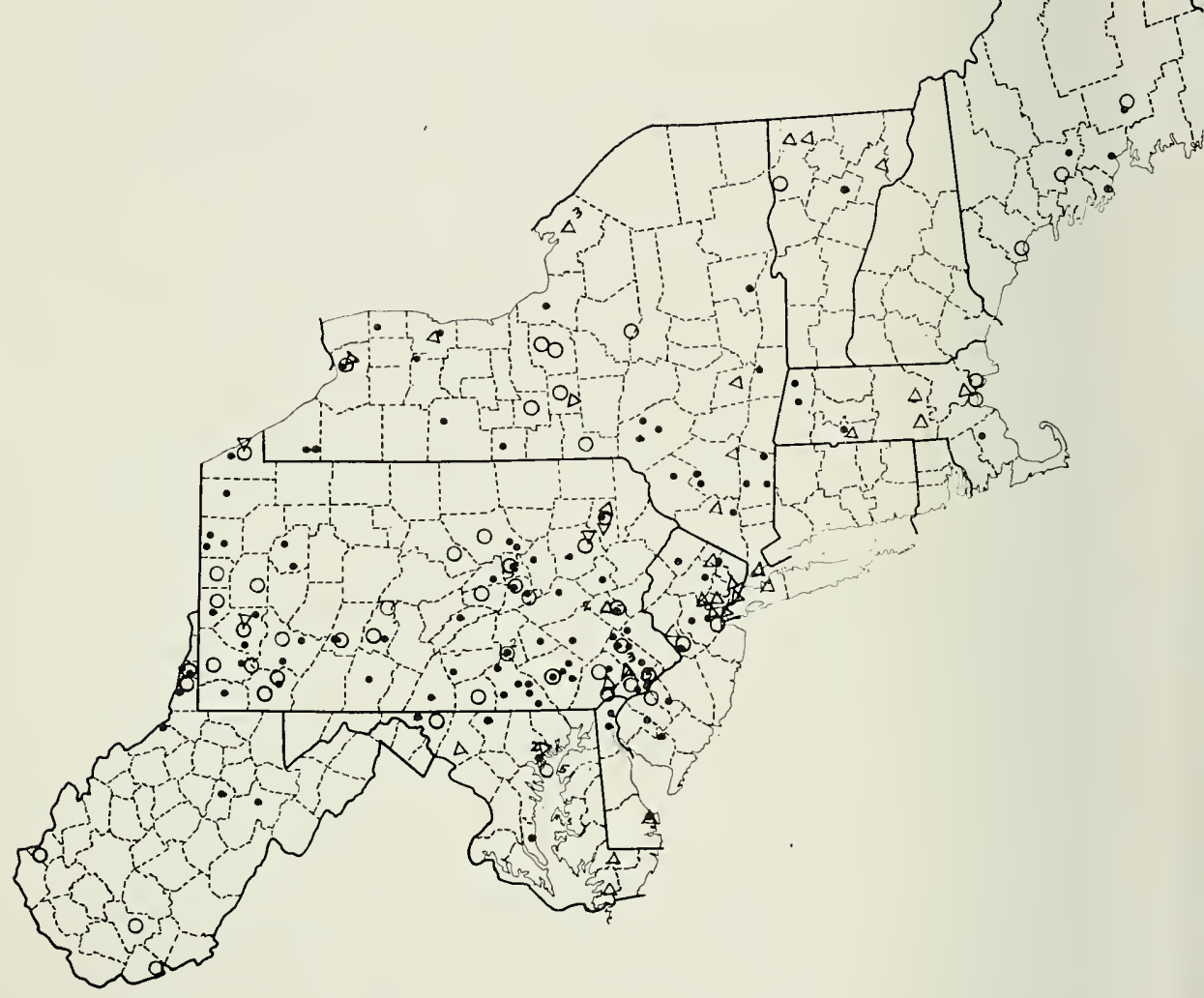

FIGURE 1. Location of Northeastern Livestock Slaughter Plant Sample, 1955.

slaughter livestock. Some of these plants are independently-owned enterprises while others are subsicliaries of national meat packers. These federally inspected plants also have more extensive distribution systems than either wholesale or local plants.

Northeastern wholesale plants are not federally inspected and are defined on the basis of annual liveweight slaughter. While some of these 
plants are as large as some federally inspected plants, they are usually independently owned and operated with less extensive supply lines and distribution systems than federally inspected plants. These plants tend to diversify in kinds of meat animals slaughtered with about 60 per cent of the plants killing three of four kinds of meat animals (Table 1). Because federal regulations prohibit the interstate shipment of meat and meat products not federally inspected, meat originating in these plants must be distributed within the states where the plants are located. However, wholesale slaughterers and local slaughterers purchase a small quantity of meat from federally inspected plants and this meat can be transported interstate. Although wholesale plants are for the most part smaller in volume than federally inspected plants, they also rely on interregional purchases for a considerable portion of their slaughter aninials.

Generally speaking, Northeastern local slaughter plants are small operations buying and selling livestock and meat at nearby markets. The typical local plant is owned and operated by one family. Usually the owner or one of the co-owners buys the livestock, manages the slaughtering operations, and sells the meat and meat products. Quite a few of these plants buy only low quality animals which they "bone out," using the meat in preparing processed meats. Still others slaughter a small number of quality animals for a select trade. Local plants do a considerable amount of custom killing, especially in the fall and early winter months. With such relatively small operations, most of these plants arrange their business so they can supply several kinds of meat and meat products to local retail outlets and consumers. Thus, they either handle a "full line of wares," that is they kill and sell the meat from three or four kinds of meat animals (Table 1), or they slaughter only one or two kinds of meat animals and rely upon purchases from other packers to complete the line of meat they are called upon to furnish.

\section{Table 1. Kinds of Meat Animals Slaughtered by Northeastern}

Slaughter Plant Sample, 1955

\begin{tabular}{|c|c|c|c|}
\hline \multirow{2}{*}{ KINDS OF MEAT ANIMALS } & \multicolumn{3}{|c|}{ Class and Number of Plants } \\
\hline & FEDERACLY INSPECTED & WHOLESALE & LOCAL \\
\hline Cattle ..... & 11 & 3 & 2 \\
\hline Hogs ....... & (i) & 4 & 2 \\
\hline 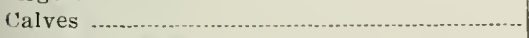 & 1 & 0 & 1 \\
\hline 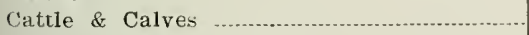 & 11 & 10 & 15 \\
\hline 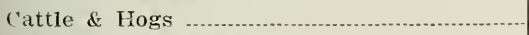 & 2 & 6 & 6 \\
\hline Calves, Sheep \& Lambs ................ & 1 & 4 & 3 \\
\hline 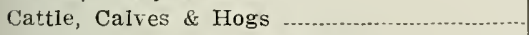 & 2 & 12 & 31 \\
\hline 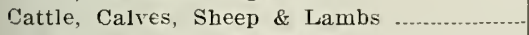 & 9 & 9 & 12 \\
\hline Cattle, Hogs, Sheep \& Lambs & 0 & 1 & 0 \\
\hline Cattle, Calves, Hogs, Sheep \& Lambs ......... & 2 & 17 & $3 s$ \\
\hline
\end{tabular}




\begin{tabular}{|c|c|c|c|}
\hline \multirow{2}{*}{ STATE } & \multicolumn{3}{|c|}{ Class AND NUMBER OF PLANTS } \\
\hline & FEDERALIY INSPECTED & WHOLESALE & LOCAL \\
\hline Delaware & 1 & 0 & 3 \\
\hline 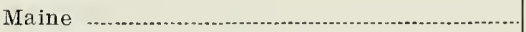 & 0 & 3 & 5 \\
\hline 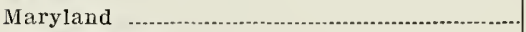 & 4 & 6 & 5 \\
\hline Massachusetts & 4 & 3 & 4 \\
\hline New Jersey & 10 & 3 & 9 \\
\hline New York & 12 & 11. & 21 \\
\hline Pennsylvania & 11 & 34 & 56 \\
\hline 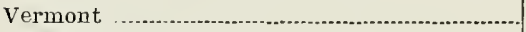 & 3 & 1. & 1 \\
\hline West Virginia & 0 & 5 & 6 \\
\hline 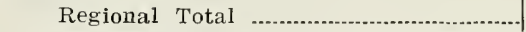 & 45 & 66 & 110 \\
\hline
\end{tabular}

\section{Selection and Location of Sample Slaughter Plants}

There were 91 federally inspected plants, 180 wholesale plants, and 447 local slaughter plants in the Northeastern region during 1955.11 One half of the federally inspected, one third of the wholesale, and one fourth of the local plants were randomly selected for use in this study. ${ }^{12}$ Of the 221 plants surveyed for this study, almost one half were located in Pennsylvania where more wholesale and local slaughter plants are in operation than in any other state in the country (Table 2 and Figure 1).

Many of these plants are located within or relatively close to large urban areas. This is especially true for the larger volume plants, such as wholesale slaughterers and federally inspected plants. Small volume plants, as local slaughterers, often have a higher per-unit production cost, but they sell their products locally. The larger volume plants, on the other hand, may be in a position to operate at a lower per-unit cost. However, these plants have larger distribution systems than do local plants and lower production costs may be offset by the higher distribution costs.

\section{Type of Inspection and Operating Period of Northeastern Slaughter Plants}

Almost all plants in the Northeastern region receive some type of periodic inspection (Table 3). In most cases this inspection is confuned to an inspection of equipment and buildings, largely for enforcing sanitary rules and regulations. However, in those plants which are federally inspected, the meat as well as the buildings and equipment

${ }^{11} N$ umber of Livestock Slanghtering Establishments, op. cit.

${ }^{12}$ For sampling procedure, see Appendix A. 
Table 3. Type of Inspection, Northeastern Slaughter Plant SAMPLE, 1955

\begin{tabular}{|c|c|c|c|c|c|c|}
\hline \multirow[b]{2}{*}{ Plant Classification } & \multicolumn{6}{|c|}{ TYPE OF 1NSPECTION } \\
\hline & FEDERAI & State & CıTY & LOCAL & $\begin{array}{c}\text { KosHeR } \\
\text { KILI }\end{array}$ & NONE \\
\hline Federally Inspected & 45 & 5 & 2 & 0 & 22 & 0 \\
\hline Wholesale & 0 & 47 & 20 & 9 & 15 & 2 \\
\hline Local & 0 & 78 & 19 & 16 & 9 & 7 \\
\hline
\end{tabular}

is inspected. Quite often there is overlapping jurisdiction with a plant receiving inspection by two or more different inspecting agencies. Of the meat distributed by all sample plants during 1955, 74 per cent of the beef, 42 per cent of the veal, 82 per cent of the pork, and 88 per cent of the lamb came from federally inspected plants (Table 4).

Table 4. Amount of Meat Distributed by Northeastern Slaughter Plant Sample, 1955

\begin{tabular}{|c|c|c|c|c|c|c|c|c|}
\hline \multirow{2}{*}{$\begin{array}{c}\text { Plant } \\
\text { CLASSIFICATION }\end{array}$} & \multicolumn{4}{|c|}{$\begin{array}{c}\text { TOTAL POUNDS OF MEAT } \\
\text { (MILLIONS) }\end{array}$} & \multicolumn{4}{|c|}{$\begin{array}{c}\text { PropoRtion of MEAT SOLD } \\
\text { BY EACH PLANT ClaAs } \\
\text { (PER CENT) }\end{array}$} \\
\hline & BEEF & VEAL & PORK & LAMí & BEEF & Veal & PORK & LAMB \\
\hline All Plants ............. & 562 & 78 & 497 & 49 & 100 & 100 & 100 & 100 \\
\hline Fed. 1nsp. Plants & 415 & 32 & 409 & 43 & 74 & 42 & 82 & 88 \\
\hline Wholesale Plants & 114 & 32 & 77 & 5 & 20 & 42 & 16 & 9 \\
\hline Local Plants ............. & 33 & 13 & 11 & 1 & 6 & 16 & 2 & 3 \\
\hline
\end{tabular}

Practically all of the plants operate 52 weeks a year (Table 5). Several factors prevent plants from closing for a week or two each year. The most important are the continuous demand for meat, the relatively high fixed cost associated with operating a packing plant, and the maintenance of clientele. Labor problems, lack of chilling, holding, and storage space are also factors which tend to keep the plants in operation all year long.

Table 5. Number of Weeks Operated by Northeastern Slaughter Plant Sample, 1955

\begin{tabular}{|c|c|c|c|c|}
\hline \multirow{2}{*}{ Plant Classification } & \multicolumn{4}{|c|}{$\begin{array}{l}\text { Number OF Plants OPERATING a SPECIFIEd } \\
\text { NuMBER of WEEkS IN } 1955\end{array}$} \\
\hline & 52 & 51 & 50 & 28 \\
\hline $\begin{array}{l}\text { Federally Inspected Plants } \\
\text { Wholesale Plants } \\
\text { Local Plants }\end{array}$ & $\begin{array}{r}44 \\
65 \\
105\end{array}$ & $\overline{-}$ & $\begin{array}{l}1 \\
1 \\
2\end{array}$ & $\frac{-}{1}$ \\
\hline
\end{tabular}

\section{Size of Plant}

The size of slaughter plants can be measured by the number of animals killed in a certain period of time. Tables 6,7 , and 8 indicate 
such measurements for Northeastern plants during 1955. However, the measurements are further refined by separating the plants according to the kinds of meat animals slaughtered. ${ }^{13}$

One of the most striking characteristics of all three classes of plants is the wide variations in the numbers of animals processed among plants in the same classification. Of course there is an extreme difference in the number of animals slaughtered in local plants when compared to either wholesale or federally inspected plants. However, the difference between plant classifications results largely from the definitions of the three plant classes. These definitions effectively segregate local, wholesale, and federally inspected plants into small, medium, and large plants respectively. The wide differences in the number of animals slaughtered anrong plants in one classification, as well as that between classifications, suggests that some plants may be using resources more efficiently than others. It may be possible in future research to isolate the most efficient resource-using plants and indicate advantages or disadvantages, if any, of large-and small-scale operations. These differences in numbers of animals slaughtered among plants also suggest that it may be possible to develop standards for such things as plant layout, type of equipment, labor requirements, etc., which will lead to a better allocation of resources.

Considering the advantages which are often associated with specialization, it would be expected that plants slaughtering one or two kinds of meat animals would be processing more animals per plant than those killing three or four kinds. However, this relationship is not very marked among plants in any classification. For example, federally inspected plants slaughtering cattle alone averaged just over 24,000 head. At the same time, those plants killing cattle, calves and lambs averaged 27,000 cattle, 13,000 calves and 38,000 lambs (Table 6). This same situation exists among wholesale and local plants (Tables 7 and 8).

The data in Tables 6,7 , and 8 also indicate a wide variation among plants in one classification killing the same kind or kinds of meat animals. The most striking variations occur among federally inspected plants where, lor example, the range in numbers slaughtered in those plants killing cattle, calves and lambs is 2,500 to 78,000 cattle, 500 to 74,000 calves, and 300 to 245,000 lambs. These wide ranges are also found among wholesale or local plants killing the same kind or kinds of meat animals. However, the numbers slanghtered are not as large.

1:"Quite often animal-unit values are assigned to different kinds of meat animals. Such units have the advantage of allowing dillerent species of animals to be summed together and direct comparisons made between the plants. However, where plants are rather specialized. animal units tend to confuse rather than enlighten. There is also considerable difficulty in assigning "the correct" weights to the different species. 


\begin{tabular}{|c|c|c|c|c|c|c|c|c|c|}
\hline 产 & 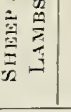 & & & & & 总 & 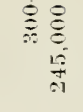 & & 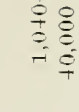 \\
\hline 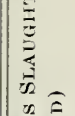 & 善 & & & 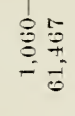 & & 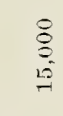 & 善品 & 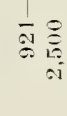 & 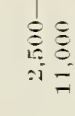 \\
\hline 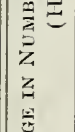 & 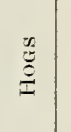 & 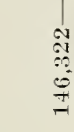 & & & 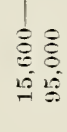 & & & 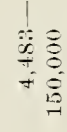 & 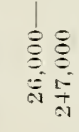 \\
\hline 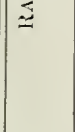 & 管 & 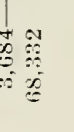 & & 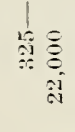 & 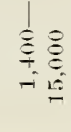 & & 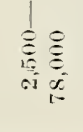 & 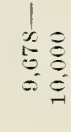 & 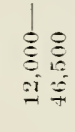 \\
\hline 紊 & 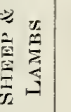 & & & & & 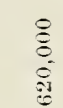 & 簿 & & . \\
\hline$\frac{\pi}{3}$ & 善 & & 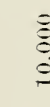 & $\frac{R}{C}$ & & 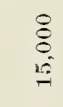 & $\begin{array}{l}\text { 员 } \\
\text { : } \\
\text { 今. }\end{array}$ & $\vec{E}$ & 量 \\
\hline$=$ & $\frac{\frac{x}{x}}{\underline{y}}$ & & & & 量 & & & $\begin{array}{l}9 \\
\substack{1 \\
0 \\
i=1 \\
i=1}\end{array}$ & 言 \\
\hline 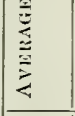 & $\begin{array}{l}0 \\
0 \\
0\end{array}$ & $\begin{array}{l}\vec{y} \\
\vec{H} \\
\vec{H}\end{array}$ & & $\underset{D}{8}$ & 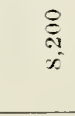 & & 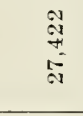 & 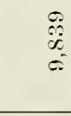 & 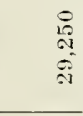 \\
\hline 言 & 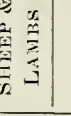 & & & & & 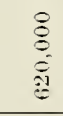 & 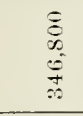 & & 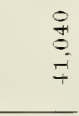 \\
\hline 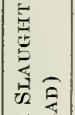 & 竞 & & $\begin{array}{l}\stackrel{8}{0} \\
=\end{array}$ & 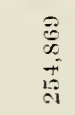 & & 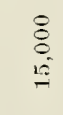 & 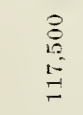 & 䨔 & 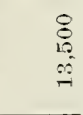 \\
\hline 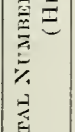 & 竞 & & & & 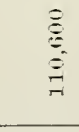 & & & 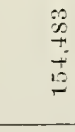 & 音 \\
\hline$=$ & 急 & 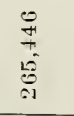 & & 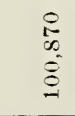 & 总 & & 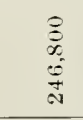 & 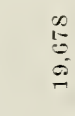 & $\begin{array}{l}8 \\
8 \\
10 \\
0.0 \\
0.0\end{array}$ \\
\hline $\begin{array}{l}\frac{1}{6} \\
\dot{\Delta}\end{array}$ & & $\Rightarrow$ & 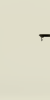 & $\bar{F}$ & s & - & $\approx$ & $\infty$ & \\
\hline 运 & & 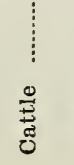 & $\frac{y}{\tilde{g}}$ & 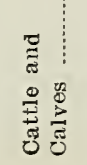 & & 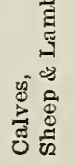 & 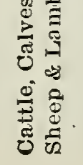 & 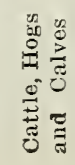 & 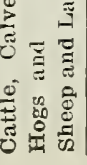 \\
\hline
\end{tabular}




\begin{tabular}{|c|c|c|c|c|c|c|c|c|c|c|}
\hline 量 & 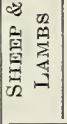 & & & & & 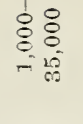 & & 点总 & $\stackrel{\circ}{\circ}$ & 誌 \\
\hline 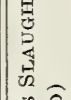 & 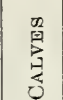 & & & 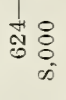 & & 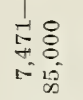 & 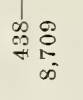 & $\begin{array}{l}8: 0 \\
8: 0 \\
\text { i. }\end{array}$ & & 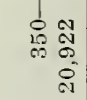 \\
\hline . & 兽 & & 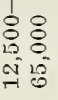 & & 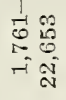 & & 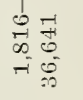 & & $\underset{:}{:}$ & 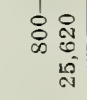 \\
\hline Fi & 署 & 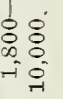 & & 喝总 & 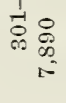 & & 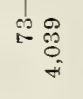 & $\begin{array}{l}8 \\
8.8 \\
\text { i. }\end{array}$ & 总 & $\begin{array}{l}8 \\
8 \\
+10 \\
-10\end{array}$ \\
\hline 童 & 事 & & & & & 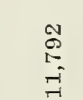 & & 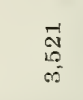 & $\stackrel{\circ}{\circ}$ & 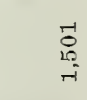 \\
\hline 昜 & 㽚 & & & $\begin{array}{l}\mathscr{8} \\
: \\
\dot{B}\end{array}$ & & 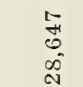 & $\begin{array}{l}\vec{F} \\
\overrightarrow{0} \\
\vec{r}\end{array}$ & 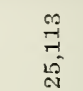 & & $\begin{array}{l}8 \\
\stackrel{8}{10} \\
10\end{array}$ \\
\hline 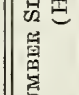 & 总 & & 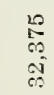 & & 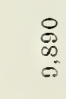 & & 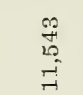 & & $\begin{array}{l}\stackrel{8}{0} \\
\text { is }\end{array}$ & $\begin{array}{l}\infty \\
\stackrel{\infty}{\infty} \\
\Gamma^{-1}\end{array}$ \\
\hline 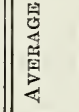 & 䁬 & 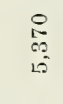 & & 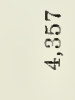 & $\begin{array}{l}8 \\
\text { i⿱ } \\
\text { ij }\end{array}$ & & $\begin{array}{l}\text { 点 } \\
\text { a }\end{array}$ & $\begin{array}{l}010 \\
{ }_{6}^{\circ} \\
10\end{array}$ & 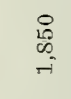 & $\begin{array}{l}0 \\
\vdots \\
0\end{array}$ \\
\hline A & 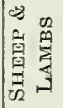 & & & & & 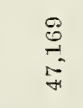 & & 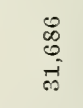 & $\stackrel{\circ}{\circ}$ & 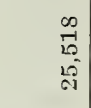 \\
\hline 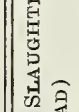 & $\begin{array}{l}\text { D. } \\
\text { 章 } \\
\end{array}$ & & & 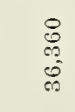 & & 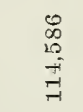 & 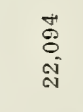 & 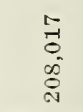 & & 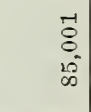 \\
\hline 思递 & 离 & & 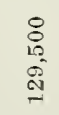 & & $\begin{array}{l}\text { ज" } \\
0 \\
0 \\
010\end{array}$ & & 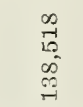 & & $\begin{array}{c}8 \\
0 \\
0\end{array}$ & 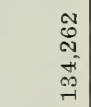 \\
\hline & 晃 & 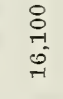 & & 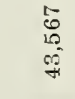 & $\begin{array}{l}\text { id } \\
\text { d. } \\
\text { di }\end{array}$ & & $\begin{array}{l}\text { di } \\
\text { di } \\
\text { id }\end{array}$ & 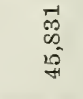 & 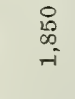 & $\begin{array}{l}\overrightarrow{0} \\
\vec{c} \\
\vec{\omega}\end{array}$ \\
\hline & & $\infty$ & H & $\stackrel{9}{9}$ & 0 & H & $\approx$ & 0 & $\rightarrow$ & $=$ \\
\hline 要 & 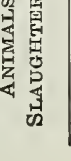 & 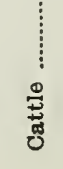 & 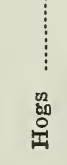 & 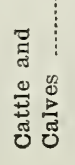 & 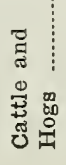 & 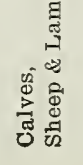 & 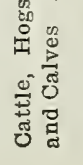 & 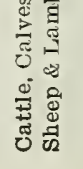 & 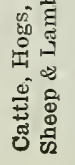 & 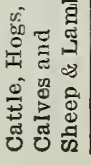 \\
\hline
\end{tabular}




\begin{tabular}{|c|c|c|c|c|c|c|c|c|c|c|}
\hline 昌 & 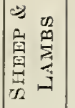 & & & & & & 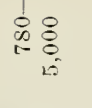 & & 品品 & 용 \\
\hline 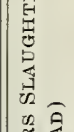 & 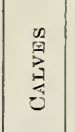 & & & & 임웜 & & 总量 & 㣌 总 & 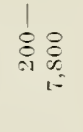 & न \\
\hline 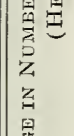 & 总 & & 总徣 & & & 童 & & 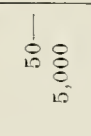 & & $\therefore 8$ \\
\hline 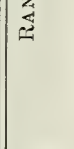 & 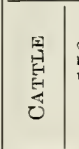 & 总 & & & 总总 & 总怘 & & 品品 & 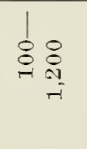 & 总: \\
\hline 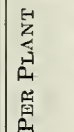 & 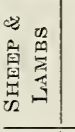 & & & & & & $\begin{array}{c}\stackrel{8}{0} \\
\text { on } \\
\text { i }\end{array}$ & & $\begin{array}{l}\infty \\
\text { 品 }\end{array}$ & 总 \\
\hline 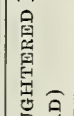 & 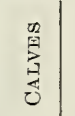 & & & & $\begin{array}{l}\text { îे } \\
\text { के }\end{array}$ & & $\begin{array}{l}\frac{1}{50} \\
\stackrel{5}{0} \\
0\end{array}$ & $\stackrel{50}{7}$ & 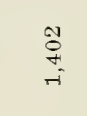 & : \\
\hline 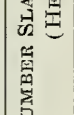 & $\stackrel{\substack{0 \\
ٍ}}{=}$ & & 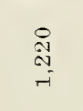 & & & $\stackrel{\wp}{\ddagger}$ & & 今े & & $\overrightarrow{\tilde{D}}$ \\
\hline 賕 & 胃 & 曽 & & & 蓠 & 总 & & 总 & 苔 & 品 \\
\hline 量 & 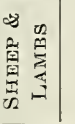 & & & & & & $\begin{array}{c}0 \\
\stackrel{D}{5} \\
0\end{array}$ & & 常 & 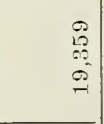 \\
\hline 器 & 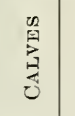 & & & & $\begin{array}{l}\infty \\
\stackrel{3}{~} \\
\stackrel{5}{10}\end{array}$ & & $\begin{array}{l}\overrightarrow{7} \\
\underset{0}{0} \\
-1\end{array}$ & $\begin{array}{l}0 \\
0 \\
0 \\
\text { A } \\
-i\end{array}$ & 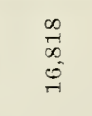 & $\begin{array}{l}10 \\
0 \\
01 \\
t^{8}\end{array}$ \\
\hline 罾王 & 总 & & $\underset{\substack{0 \\
\text { in } \\
\text { i }}}{ }$ & & & $\underset{0 i}{0}$ & & 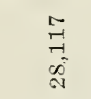 & & 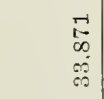 \\
\hline 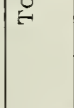 & 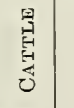 & ît & & & 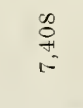 & 兽 & & 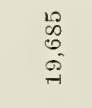 & : & 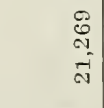 \\
\hline & & $\infty$ & N & $r$ & $\stackrel{B}{n}$ & 0 & $\infty$ & $\vec{\omega}$ & $\stackrel{ㄱ}{7}$ & $\begin{array}{l}\infty \\
\infty\end{array}$ \\
\hline 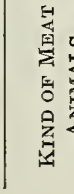 & & & 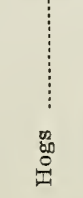 & 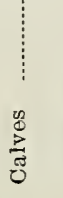 & 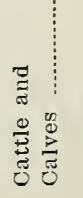 & 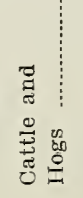 & 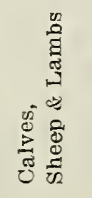 & 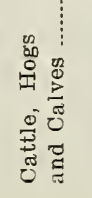 & 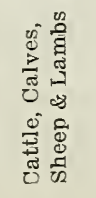 & 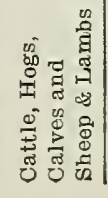 \\
\hline
\end{tabular}


For example, in wholesale plants killing cattle, calves and lambs the ranges are 2,600 to 10,000 cattle, 2,000 to 104,000 calves and 477 to 7,000 iambs. The ranges for local plants killing the same kinds of animals are 100 to 1,200 cattle, 200 to 7,800 calves and 50 to 520 lambs.

From the data presented in Tables 6,7 , and 8 , it becomes increasingly clear that the variations among plants in one classification as well as that between plant classifications is so great that a statement of size based on animal numbers alone is not too meaningful. A more meaningful measure would be pounds of either livestock or meat handled.

\section{Limiting Factors of Slaughterers}

When the plant operators were asked what factors limited their operations, the most frequently given answers were, in their words, "not enough chilling space," "lack of skilled labor," "amount of business," "full capacity," "consumer, market and trade demand," and other problems connected with internal plant facilities and operations (Table 9). The factors listed in Table 9 are those enumerated by plant operators, and it is likely that several of them could be grouped together under one

\section{Table 9. Limiting Factors of Northeastern Slaughter Plant} SAMPLE, 1955

\begin{tabular}{|c|c|c|c|}
\hline \multirow[b]{2}{*}{ LIMITING FACTOR } & \multicolumn{3}{|c|}{ Plant Classification (Responses) } \\
\hline & $\begin{array}{l}\text { FEDERALLY } \\
\text { INSPECTED }\end{array}$ & \multirow{2}{*}{$\frac{\text { WHOLESALE }}{2}$} & \multirow{2}{*}{ LOCAL } \\
\hline Full capacity & 19 & & \\
\hline Not enough chilling space & 17 & 20 & 38 \\
\hline Skilled labor & 6 & 16 & 20 \\
\hline Killing space & 一 & 4 & 6 \\
\hline Amount of business & 13 & 23 & - \\
\hline Price changes & 3 & - & - \\
\hline Storage room & 一 & 5 & - \\
\hline No profit & - & 2 & 1 \\
\hline Lack of customers & - & 3 & - \\
\hline Operating time & 一 & 1. & - \\
\hline Lack of livestock & 一 & 1 & 2 \\
\hline Too much competition & - & 1 & - \\
\hline 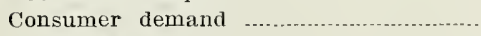 & - & - & 12 \\
\hline 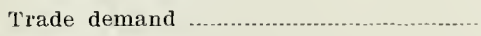 & - & - & 6 \\
\hline 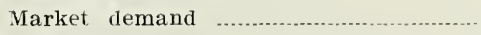 & - & - & 16 \\
\hline Rail space ......... & 一 & $\ldots$ & 3 \\
\hline Holding space & - & - & 7 \\
\hline Plant area & - & - & 7 \\
\hline 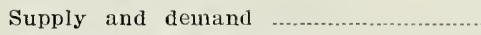 & - & - & 10 \\
\hline Manufacturing equipment & - & - & 1 \\
\hline Business conditions & 一 & — & 6 \\
\hline No market for meat & 一 & - & 1 \\
\hline Do not wish to expand & - & - & 3 \\
\hline No sales force & - & - & 2 \\
\hline 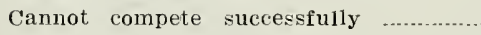 & - & - & 1 \\
\hline None & 一 & - & 3 \\
\hline
\end{tabular}


category. For instance, slaughterers may have used the terms consumer, trade, and market demand interchangeably when they were referring to market clemand. However, it may be that each of these categories do have a specific and separate meaning to people connected with the livestock inclustry (as they do indeed among economists!) and for that reason the categories have not been combined.

Over-all, it appears that many Northeastern slaughtering operations may be limited because of insufficient refrigeration space or because output is pressing against plant capacity. That is, output may be pressing against present plant capacity given the existing type of equipment, labor force, plant facilities, and layout.

Several of the local slaughterers stated that the lack of demand limited their operations, while none of the federally inspected or wholesale slaughterers listed dentand as a limiting factor. It may be that local slaughterers are unable to distinguish between inadequate demand and their inability to supply meat and meat products to larger retail and wholesale outlets or their difficulty in selling meat at prices which they think they should get.

The smaller volume slaughter plants may also list demand as a factor when the real predominant limiting factor is the kind of animals they slaughter. The broken and odd lots they purchase and slaughter may not be so easy to sell and they in turn label this insufficient demand.

A number of small local and wholesale plants are confronted with another aspect of supply and demand which seemingly does not affect larger meat packing concerns. That is the problem of being able to supply chain stores and other large retail outlets with a continuous volume of meat large enough to satisfy the demands of consumers patronizing these outlets. Because small volume plants are unable to provide a sufficient supply of meat to large retail organizations, they are by-passed in favor of large volume packers who can insure a continuous volume of meat and meat products. These smaller plants may contemplate expanding with the expectations of doing business with these larger retail outlets, but to do so is quite expensive and constitutes a rather ligh risk venture. On the other hand, if expansion does not take place, many local and wholesale plants must be content with supplying outlets demanding relatively small quantities of meat and meat products.

Our modern transportation industry was given a vote of confidence when only three plants listed the supply of livestock as a limiting factor. From this we might assume the channels of supply are working satisfactorily to insure the slaughterers an adequate and continuous supply of livestock and that future research and planning in the Northeastern region might well be oriented in the area of internal plant problems. 


\section{Livestock Procured from Other Regions}

The Northeastern region has long been a deficit meat producing region with a large majority of all meat animals, except dairy cattle and calves, being imported from other regions. Of the animals slaughtered in sample Northeastem plants during 1955 approximately 70 per cent of the beef steers and heifers, 85 per cent of the hogs, and 90 per cent of the sheep and lambs were procured in other regions (Table 10). While all three classes of plants participated in this mass interregional procurement, federally inspected plants accounted for most of it. For example, in 1955 locals obtained less than 15 per cent of their meat animals from other regions, while federally inspected plants purchased roughly 80 per cent of their beef steers and heifers, 95 per cent of their hogs and 99 per cent of their lambs from other regions (Figures 11 and 12). Wholesale plants were between these extremes procuring approximately 40 to 50 per cent of their meat animals from outside of the Northeastern region (Table 13).

When the plant operators were asked to list their reasons for procuring livestock in other regions a majority indicated they did so because

Table 10. Sources of Livestock for Northeasteri Slaughter Plant SAMPLE, 1955

\begin{tabular}{|c|c|c|c|c|c|}
\hline \multirow{2}{*}{$\begin{array}{l}\text { KIND OR Class } \\
\text { OF MEAT ANIMAL }\end{array}$} & \multirow{2}{*}{$\begin{array}{c}\text { Total NuMBER } \\
\text { SLAUGHTERED }\end{array}$} & \multicolumn{4}{|c|}{ SOURCE OF SUPPLY } \\
\hline & & \multicolumn{2}{|c|}{ Northeastern Regtox } & \multicolumn{2}{|c|}{ Other Regions } \\
\hline All Cattle & $\begin{array}{c}\text { Head } \\
979,576\end{array}$ & $\begin{array}{c}\text { Numbcr } \\
530,7 т 0\end{array}$ & $\begin{array}{c}\text { Per cent } \\
5 t\end{array}$ & $\begin{array}{l}\text { Number } \\
\pm \pm 8,806\end{array}$ & $\begin{array}{c}P c r e c u t \\
46\end{array}$ \\
\hline Beef Steers \& Heifers & 562,392 & 163,582 & 29 & 398,810 & 71 \\
\hline Bulis & 63,683 & 39,198 & 62 & 24.485 & 38 \\
\hline Gther Cattle & 353,501 & 327,990 & 93 & 25,511 & 7 \\
\hline Calves & $1,023,870$ & 835,418 & - 82 & 188,452 & 18 \\
\hline Hogs & $3,030,467$ & 479,445 & 16 & $2,551,022$ & 84 \\
\hline Sheep \& Lambs ........ & $1,145,173$ & 96,354 & s & $1,049,119$ & 92 \\
\hline
\end{tabular}

Table 11. Sources of Livestock for Logal Slaughter Plants, NORTHEASTERN Region, 1955

\begin{tabular}{|c|c|c|c|c|c|}
\hline \multirow{2}{*}{$\begin{array}{l}\text { KIND OR Class } \\
\text { OF MEAT ANTMAL. }\end{array}$} & \multirow{2}{*}{$\begin{array}{l}\text { TOTAL NUMBER } \\
\text { SLALGHTERED }\end{array}$} & \multicolumn{4}{|c|}{ SOLRCE OF SIPPLI } \\
\hline & & \multicolumn{2}{|c|}{ NORTHIEATERN RFGION } & \multicolumn{2}{|c|}{ OTHER RF(iInNA } \\
\hline & Head. & Vumbrr & Pr) ("थाI & Numbrr & 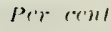 \\
\hline All Cattle ........................ & 59,149 & $\overline{5} \bar{x}, 306$ & $9+$ & $3.8+3$ & $1 i$ \\
\hline Beef Steers \& Heifers .. & 30,017 & $27,0631)$ & 90 & 3,1117 & 10 \\
\hline Bulls ........................................ & 5,558 & 5,213 & 94 & $3 \pm 5$ & i \\
\hline other Cattle .... & 23,574 & 23,093 & 98 & 481 & 2 \\
\hline Calves ..................... & 153,572 & 142,963 & 93 & 10,609 & 7 \\
\hline Hogs ....................... & 66,933 & 57,972 & 57 & 8,961 & 13 \\
\hline Sheep \& Lambs ..... & 29.472 & $2+.911$ & 85 & 4,561 & 15 \\
\hline
\end{tabular}


there was a "wider selection" of "quality animals" in "sufficient quantities" and at "favorable prices" (Table 14). "Dependability" and "convenience" were also factors influencing individual decisions to procure livestock in other regions. With the exception of prices, the reasons given for procuring livestock outside of the region are all associated with problems in the procurement of livestock. Thus it appears that, even

Table 12. Sources of Livestock for Federally Inspegted Slaughter Plants, Northeastern Region, 1955

\begin{tabular}{|c|c|c|c|c|c|}
\hline \multirow{2}{*}{$\begin{array}{l}\text { KIND OR CLASS } \\
\text { OF MEAT ANIMAL }\end{array}$} & \multirow{2}{*}{$\begin{array}{l}\text { TOTAL NUMBER } \\
\text { SLAUGHTERED }\end{array}$} & \multicolumn{4}{|c|}{ SOURCE OF SUPPLY } \\
\hline & & \multicolumn{2}{|c|}{ Northeastern Regron } & \multicolumn{2}{|c|}{ Other Regrons } \\
\hline All Cattle & $\begin{array}{l}\text { Ilead } \\
714,494\end{array}$ & $\begin{array}{c}\text { Number } \\
333.059\end{array}$ & Per cent & Number & Per cent \\
\hline Beef Stcers \& Heifers & 438,664 & 91,444 & 21 & 347,220 & 79 \\
\hline BuIls & 37,377 & 17,458 & 47 & 19,919 & 53 \\
\hline 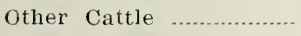 & 238,453 & 224,157 & 94 & 14,296 & 6 \\
\hline Calves .................... & $+14,840$ & 288,807 & 70 & 126,033 & 30 \\
\hline Hogs & $2,498,045$ & 156,302 & 6 & $2,341,743$ & 94 \\
\hline Sheep \& Lambs & $1,010,418$ & 11,518 & 1 & 998,900 & 99 \\
\hline
\end{tabular}

Table 13. Solrces of Livestock for Wholesale Slaughter Plants, Northeastern Region, 1955

\begin{tabular}{|c|c|c|c|c|c|}
\hline \multirow{2}{*}{$\begin{array}{l}\text { KYND OR Class } \\
\text { OF MEAT ANIMAL }\end{array}$} & \multirow{2}{*}{$\begin{array}{l}\text { Total Number } \\
\text { SlaUghtered }\end{array}$} & \multicolumn{4}{|c|}{ SoURCE OF SuPPLY } \\
\hline & & \multicolumn{2}{|c|}{ Northeastern Regron } & \multicolumn{2}{|c|}{ OTHER REGroNs } \\
\hline All Cattle & $\begin{array}{l}\text { Hcad } \\
205,933\end{array}$ & $\begin{array}{l}\text { Number } \\
142,405\end{array}$ & $\begin{array}{c}\text { Per cent } \\
69\end{array}$ & $\begin{array}{r}\text { Numbcr } \\
63,528\end{array}$ & $\begin{array}{c}\text { Per cent } \\
31\end{array}$ \\
\hline Beef Steers \& Heifer's .. & 93,711 & 45,138 & 48 & 48,573 & 52 \\
\hline 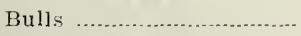 & $20,74 \mathrm{~S}$ & 16.527 & 80 & 4,221 & 20 \\
\hline Other Cattle & 91,474 & 80,740 & 88 & 10,734 & 12 \\
\hline 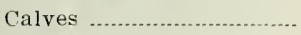 & 455,458 & 403,648 & 89 & 51,810 & 11 \\
\hline Hogs & 465,489 & 265,171 & 57 & $200,31 \mathrm{~S}$ & 43 \\
\hline Sheep \& Lambs ................ & 105,593 & 59,925 & 57 & 45,658 & 43 \\
\hline
\end{tabular}

Table 14. Reasons Given for Procuring Livestock Outside of the Northeastern Region by Northeastern Slaughter Plant Sample, 1955

\begin{tabular}{|c|c|c|c|}
\hline \multirow[b]{2}{*}{ REAson Grven } & \multicolumn{3}{|c|}{ Plant Classification (Responses) } \\
\hline & $\begin{array}{l}\text { FEDERALLY } \\
\text { INSPECTED }\end{array}$ & WHOLESALE & LOCAL \\
\hline Market Dcmand & 3 & - & - \\
\hline Quality _... & 27 & $4: 3$ & 30 \\
\hline Quantity & 25 & 42 & $2 f$ \\
\hline Priee …….... & !) & 14 & 7 \\
\hline Convenience & 2 & s & 11 \\
\hline Solection Offered & 12 & 11 & - \\
\hline Seasonal or Oeasional Eargain ..... & 3 & - & 4 \\
\hline Competition & 1. & - & \\
\hline Dressing Percentage & - & - & 3 \\
\hline lependable Source of Supply ...................... & - & 13 & 2 \\
\hline inill out Loads ..... & - & - & 2 \\
\hline Close Markets & - & \pm & 3 \\
\hline Quick, Cheap Transportation .......... & - & - & 3 \\
\hline
\end{tabular}


on an individual plant basis, the primary reason for obtaining neat animals outside of the Northeastern region is the inadequate supply of meat animals within the region.

The great disparity between meat production and consumption in the region, together with the reasons given by slaughterers for procuring livestock outside of the Northeastern region, indicates that meat production might be profitably expanded in the area. However, livestock production has not expanded because of the costs of growing grain or transporting it into the area, the costs of increasing the number of breeding animals, and the use of productive resources in enterprises which likely have less utility, than alternative uses.

\section{Amount and Sources of Livestock Procured Within the Northeastern Region}

As indicated in Figure 10, a large majority of slaughter dairy cattle and calves are obtained within the region. For the year 1955 over 90 per cent of the dairy cattle, 80 per cent of the calves and 60 per cent of the bulls slaughtered in the sample plants were obtained within the region. During the same period only 29 per cent of the beef steers and heifers, 16 per cent of the hogs, and 8 per cent of the sheep and lambs were purchased in the region.

Local and wholesale slaughterers obtained most of their slaughter livestock in the Northeast while federally inspected plants obtained most of their purchases in other areas. In the aggregate picture, the procurement pattern of local and wholesale slaughterers is somewhat obscured by the activities of large volume packers (Table 12). During 1955, for example, locals obtained over 85 per cent of their hogs and lambs, and well over 90 per cent of all other meat animals within the region (Table il). During the same period wholesale plants procured between 50 and 60 per cent of their slaughter animals within the Northeastern region (Table 13).

Most of the slaughter animals obtained within the region are procured at either terminals or auctions. Purchases from these two sources accounted for well over two thirds of all meat animals bought by sample plants in the Northeastern region (Figure 2). Procurements from dealers and directly from farmers were of relatively minor importance, excepting the direct purchases of hogs. Approximately one fourth of all logs bought in the region were obtained directly from farmers. Auction markets were the most important source of dairy cattle and calves, and terminal markets the most important source of lambs, hogs, beef steers and heifers. 
All Cotrle

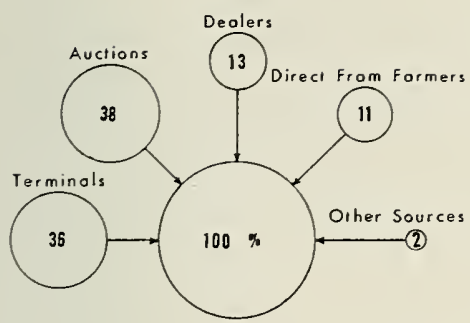

Bulls
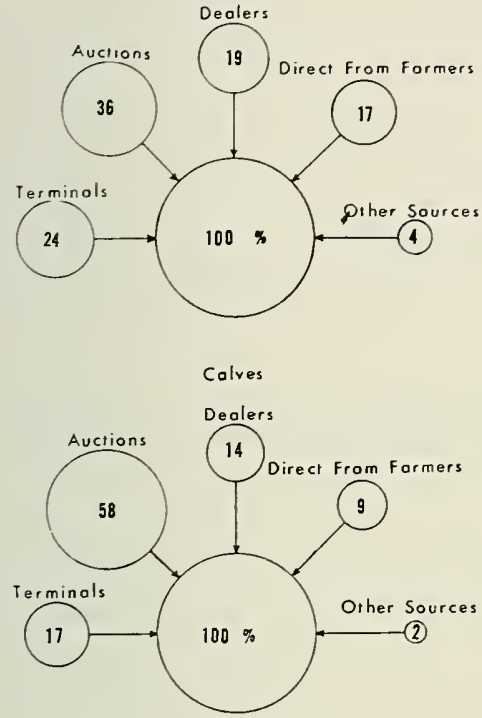

Beef Steers \& Heifers

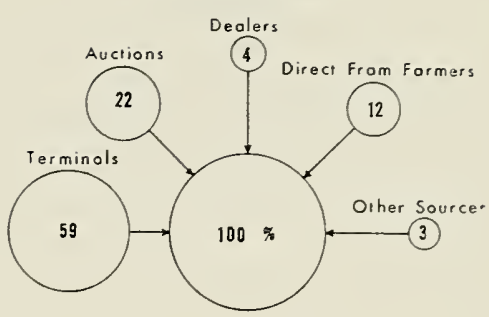

Other Cattle

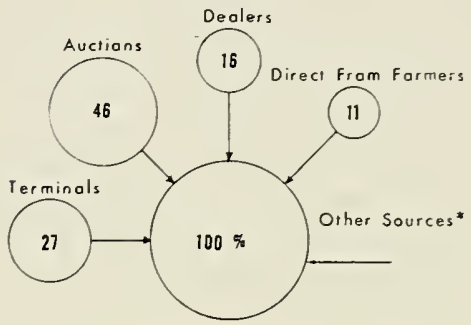

Hogs

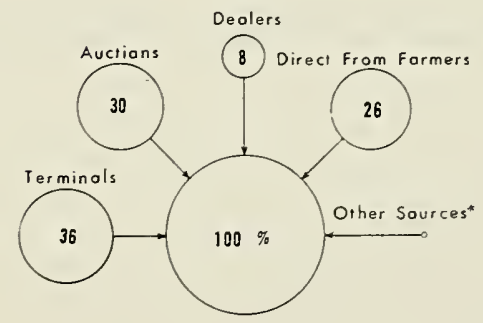

Sheep \& lambs

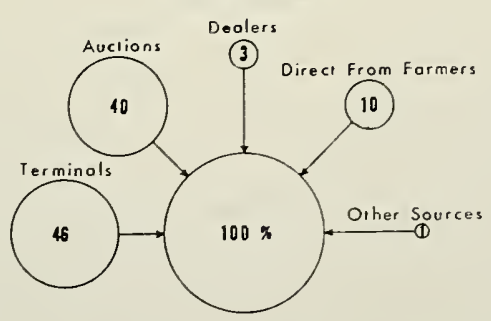

*less than .005

FIGURE 2. Sources of Livestock Procured Within the Northeastern Region, Northeastern Slaughter Plant Sample, 1955. 
When the sources of meat animals used by individual plant classes are isolated from the aggregate procurement pattern, several differences can be seen. The procurement pattern of federally inspected plants is quiie smilar to the aggregate pattern, with the greatest exception occurring in direct purchasing of hogs (Figure 3). Roughly 40 per cent of the slaughter hogs procured by federally inspected plants were purchased directly from farmers, compared to 26 per cent when all plants are considered. On the other hand, the procurement pattern of local plants differs greatly from the aggregate pattern (Figure 5). When all plants are considered, direct purchases from farmers were not too important, accounting for about 15 per cent of all slaughter animals. Local plants, however, obtained roughly 30 to 35 per cent of their livestock directly from farmers. Local plants also had a greater dependence upon purchases at auctions than did federally inspected or wholesale plants. Altogether local plants obtained approximately 75 per cent of their meat animals from auction markets and directly from famers. In comparison, federally inspected plants procured 50 per cent of their slanghter livestock from auctions and farmers and wholesale plants obtained 55 per cent of their livestock from these sources. The pattern of procurement by wholesale plants is not very different from the aggregate pattern for all plants (Figure 4).

\section{Sales Outlets Used for Distributing Meat and Meat Products}

The distribution patterns of slaughter plants are largely determined by the demands of retail and wholesale meat buyers. These buyer demands are in turn largely determined by consumer demand. The choice among slaughter plants, however, is influenced by a number of factors associated with the slaughter plants. The kind and grade of livestock slaughtered, the ability to supply a continuous volume of meat, whether or not the meat is federally inspected and graded, personal friendship and preference, salesmanship of slaughterers, relative prices for meat among slaughterers, extent of carcass breakdown, and other services rendered by slaughterers are examples of the myriad forces which influence the decisions of meat buyers when selecting among slaughter plants.

The outlets to which a slaughterer sells his meat change in importance over a period of time. Some buyers quit altogether while, others decrease their purchases. At the same time new customers are adcled, and others increase their purchases. In the aggregate, however, many of these factors offset each other and fairly clear marketing patterns tend to develop. Of major importance are sales to retail markets, jobbers and 

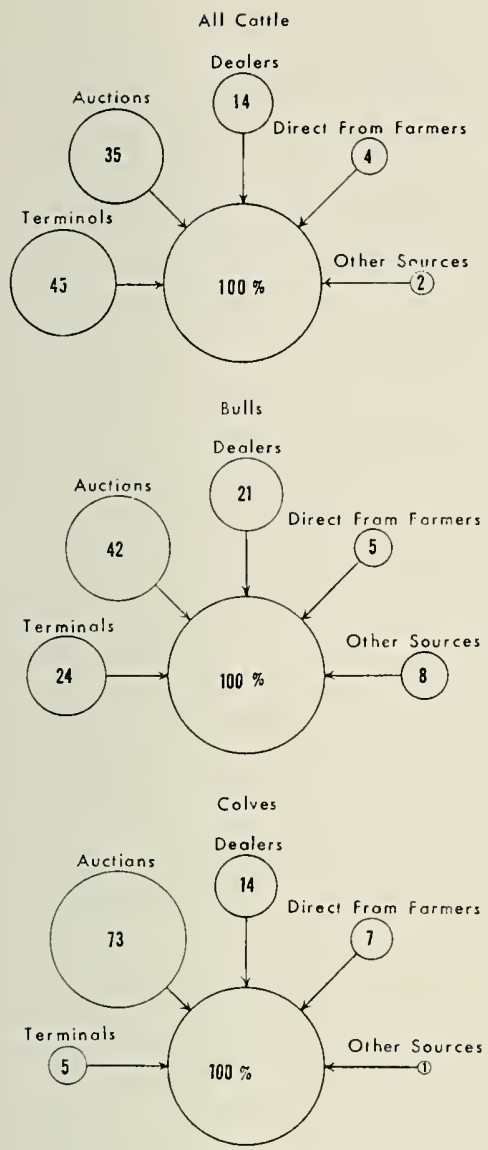

Beef Steers \& Heifers

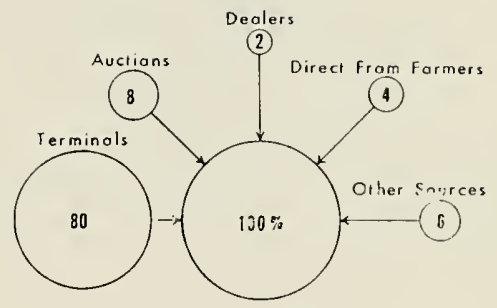

Oitier Cortle

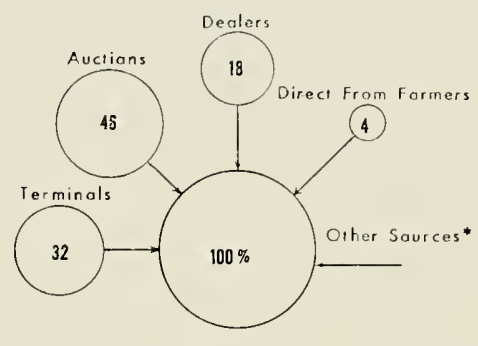

Hogs

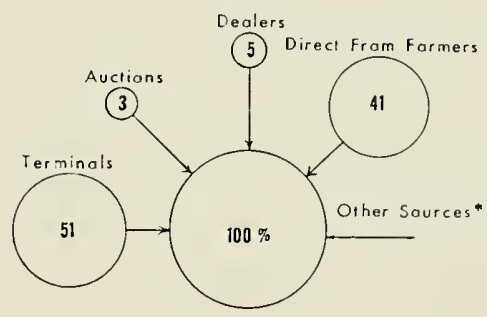

Sheep \& Lambs

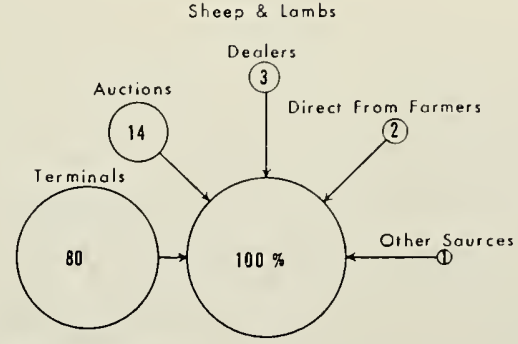

* None procured from other sources

FIGURE 3. Sources of Livestock Procured Within the Northeastern Region, Northeastern Federally Inspected Slaughter Plants, 1955. 

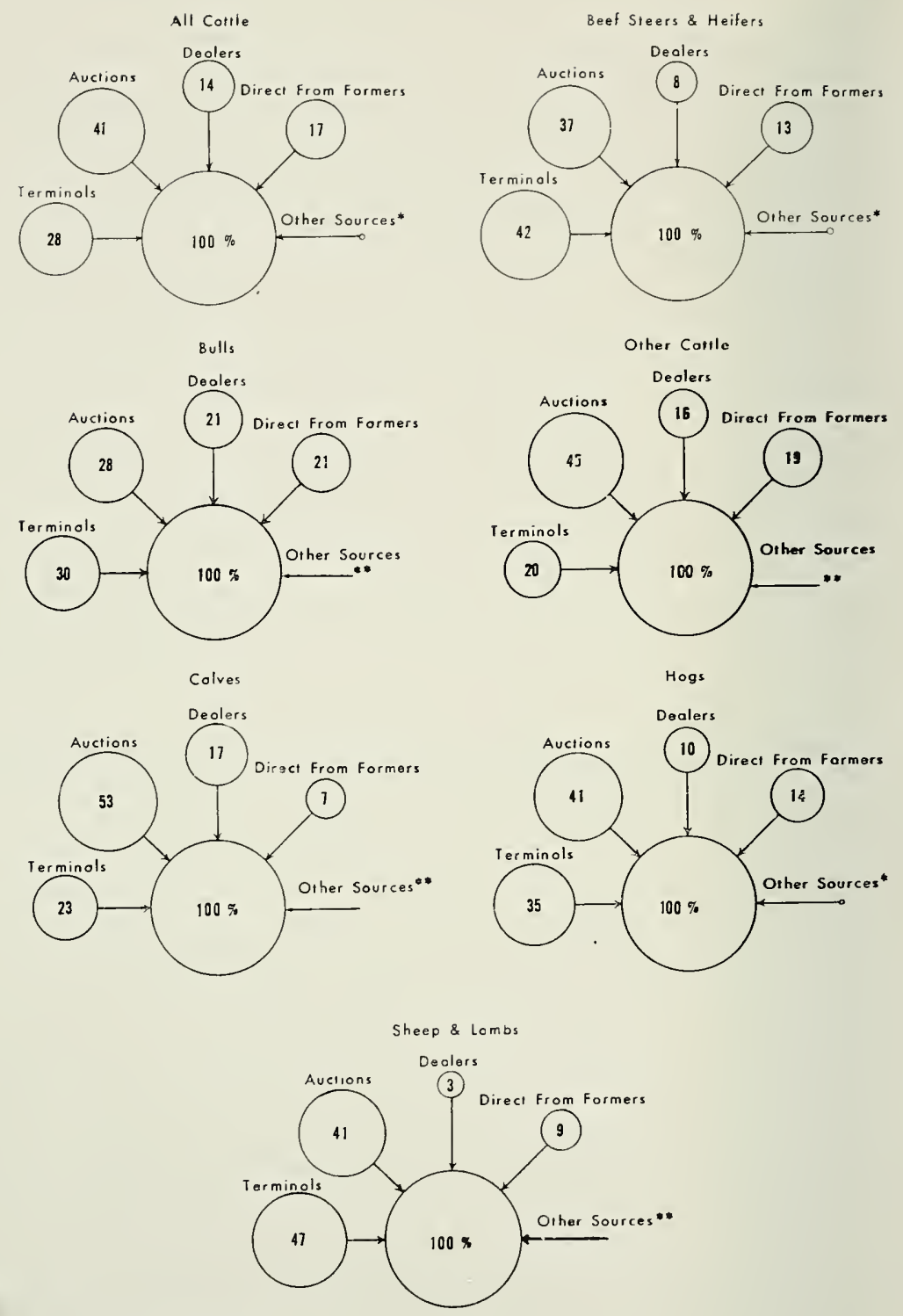

* Jess than .005
* None procured from other sources

FIGURE 4. Sources of Livestock Procured Within the Northeastern Region, Northeastern Wholesale Slaughter Plants, 1955. 


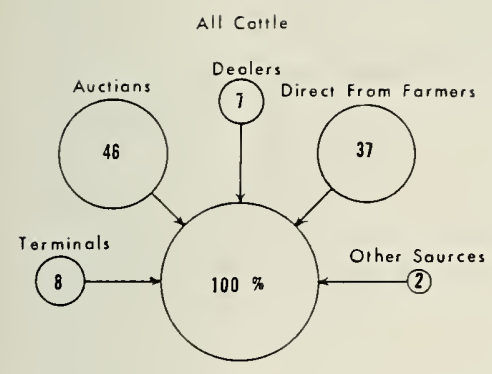

Beef Steers \& Heifers
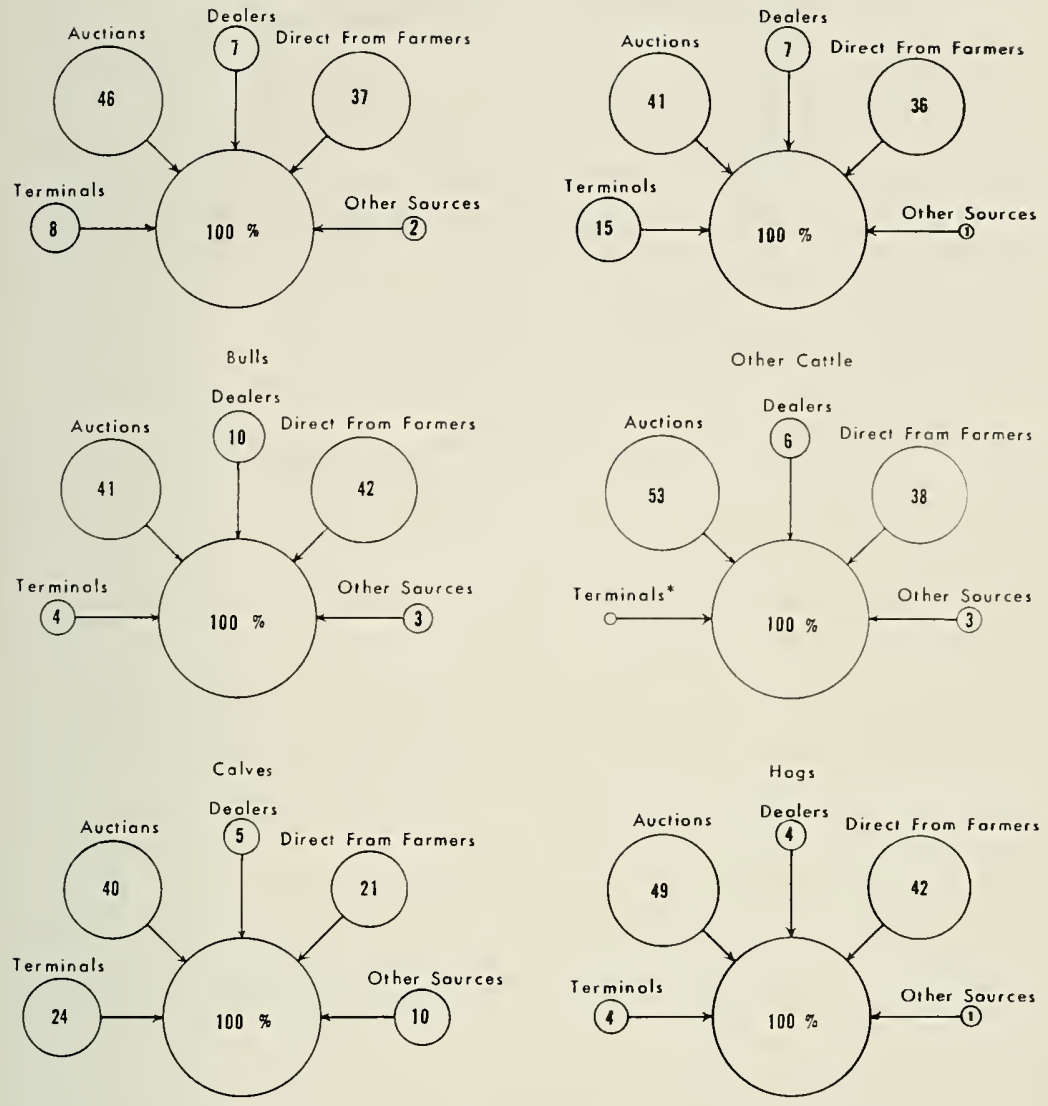

Sheep \& Lombs

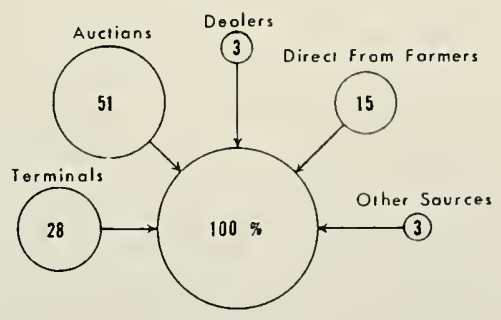

*less than .005

FIGURE 5. Sources of Livestock Procured Within the Northeastern Region, Northeastern Local Slaughter Plants, 1955. 


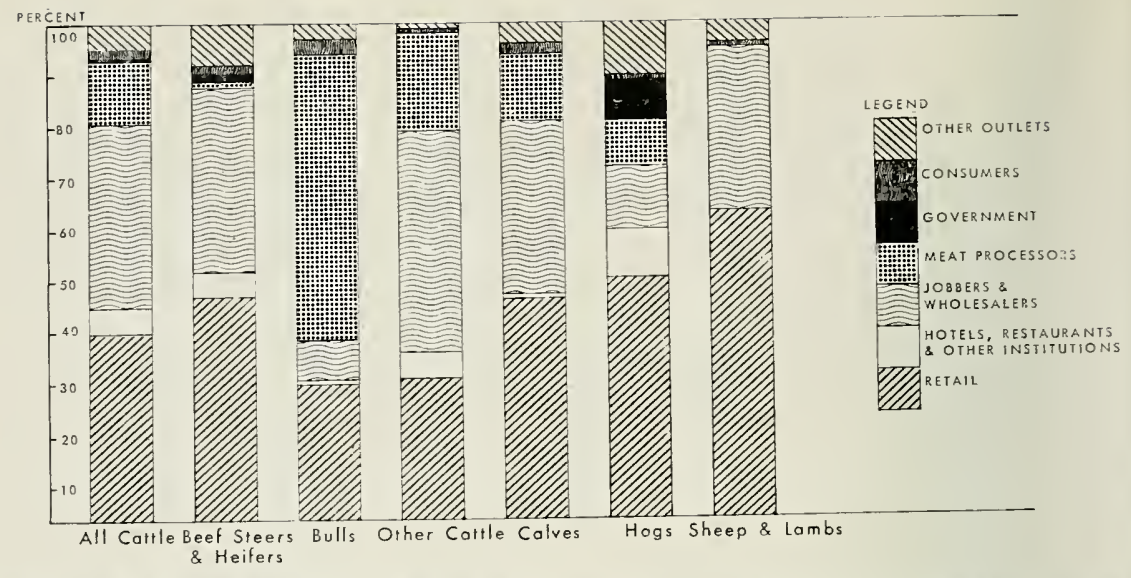

FIGURE 6. The Amount of Meat and Meat Products by Kind of Meat Animal Sold to Different Sales Outlets by Northeastern Slaughter Plant Sample, 1955.

wholesalers, and meat processors. Sales directly to consumers, government agencies, hotels, restaurants and other outlets are of minor importance except in individual cases.

In this study, the movement of meat and meat products from slaughter plants to consumers was not completely traced. Instead, the task was to determine the initial movement of meat and meat products. That is, what were the sales outlets being used by slaughterers and which ones were most important?

To ascertain the amount of meat sold to each of these outlets, it was necessary to convert live animals into dressed carcass weight. This was accomplished by converting livestock numbers first to live weight and then converting live weight into dressed carcass weight (Appendices B, $\mathrm{D}$ and E). ${ }^{14}$

During 1955 the largest proportion of meat and meat products marketed by sample Northeastern slaughterers was sold to retail outlets. The second most important outlet used was jobbers and wholesalers. The combined sales to these two outlets accounted for 75 per cent of the beef, 79 per cent of the veal, 6l per cent of the pork and 95 per cent of the lamb) (Figure 6). Sales to meat processors ranked third in importance, anominting to 12 per cent of the beel, 14 per cent of the veal and 9 per

"Animals were converted to liveweight by using the average liveweight value for each type of meat animal in each of the Nortlieastern states during 1955. The United States average-dressed weight for each type of meat animal was divided by the United States average-liveweight and expressed as the dressing percentage. These dressing percentages were then applied to the liveweight values of the animals slaughtered to obtain total pounds of meat for distributios. Tine autbor is cognizant of limitations associated with this procedure. However, no method of ascertaining liveweights, dressing percentages, and dressed weights is precisely correct unless each animal is handled individually. 


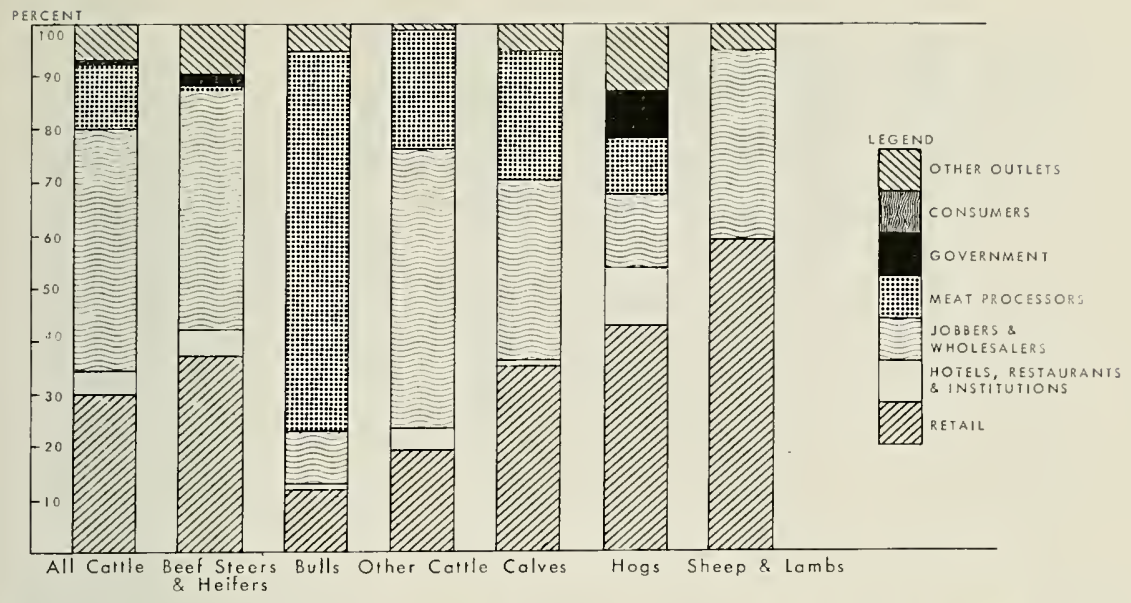

FIGURE 7. The Amount of Meat and Meat Products by Kind of Meat Animal Sold to Different Sales Outlets by Northeastern Federally Inspected Slaughter Plants, 1955.

cent of the pork. The remaining meat was sold to hotels, restaurants, government agencies, consumers and other outlets.

These aggregate figures conceal a marketing pattern of considerable importance in this region. Dairy cattle, bulls and calves constitute a s.zable majority of all meat animals produced and marketed in the region, and the use made of the meat from these animals, in addition to the way it is distributed, is quite important to farmers, as well as others connected with the livestock industry. In general, the eating quality of

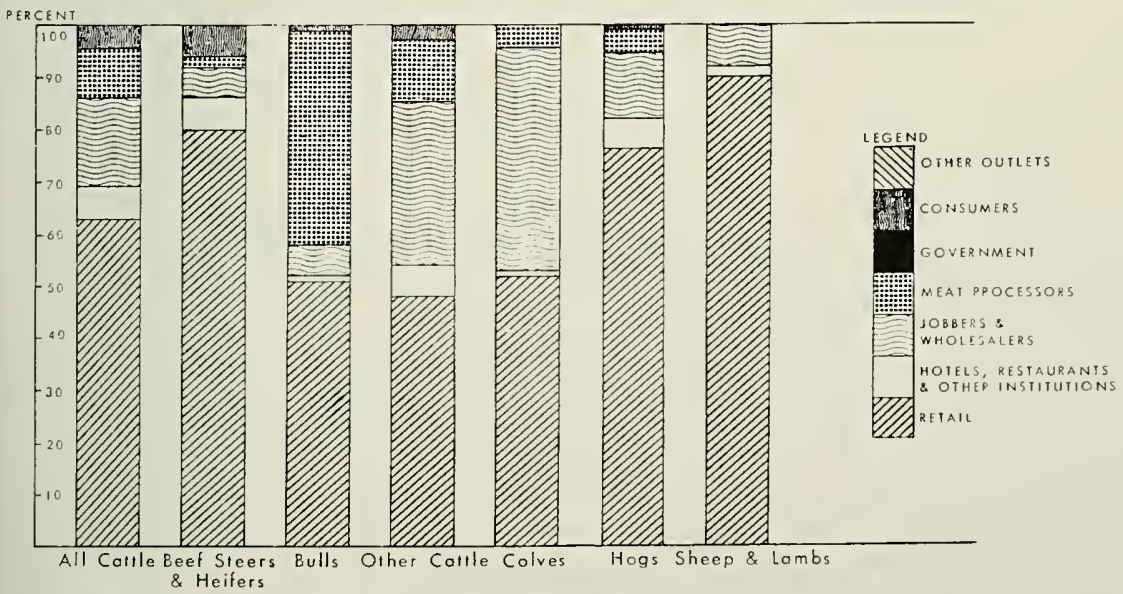

FIGURE 8. The Amount of Meat and Meat Products by Kind of Meat Animal Sold to Different Sales Outlets by Northeastern Wholesale Slaughter Plants, 1955. 


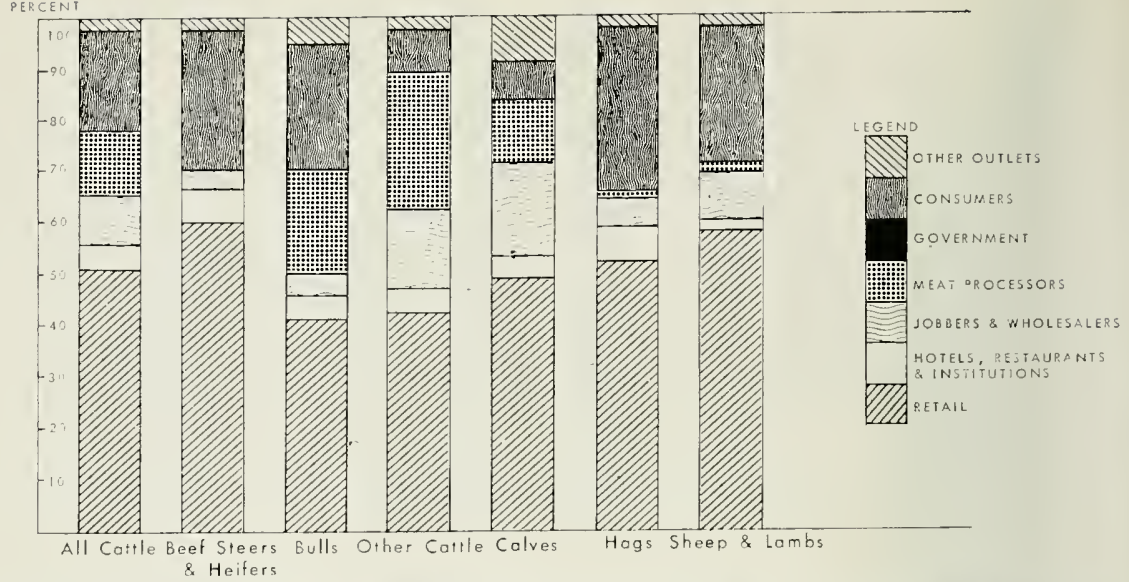

FIGURE 9. The Amount of Meat and Meat Products by Kind of Meat Animal Sold to Different Sales Outlets by Northeastern Local Slaughter Plants, 1955.

retail cuts of beel from dairy cattle and bulls is inferior to that from beef steers and heifers. Consequently, a large amount of this beef is sold to meat processors who use it in preparing sausages, meat loaves, canned and other processed meats.

The pattern of distribution for individual plant classifications differs quite significantly from one class to another. While federally inspected plants depend upon sales to retail outlets, and jobbers and wholesalers, the importance of each outlet is approximately the same (Figure 7). Wholesale plants, however, are heavily dependent upon sales to retail outlets with sales to jobbers and wholesalers representing a second but much less important outlet (Figure 8). Locals, on the other hand, sell about half of their meat to retail outlets, one fourth directly to consumers and the remaining fourth largely to meat processors, jobbers and wholesalers (Figure 9).

\section{The Proportion of Meat Sold in Different Forms of Carcass Breakdown}

The kind and degree of carcass breakdown is generally determined by the demand from markets being served and the kind and grade of meat animals slaughtered. Usually the higher grades of cattle, calves, and lambs are sold either as whole, half, or quarter carcasses. On the other hand, $\log$ carcasses of comparable grades are usually further separated and sold as wholesale cuts, either fresh or cured.

Considerable quantities of the lower grade animals are sold as boned meat. This is especially true of dairy cattle and bulls. At the same time, 


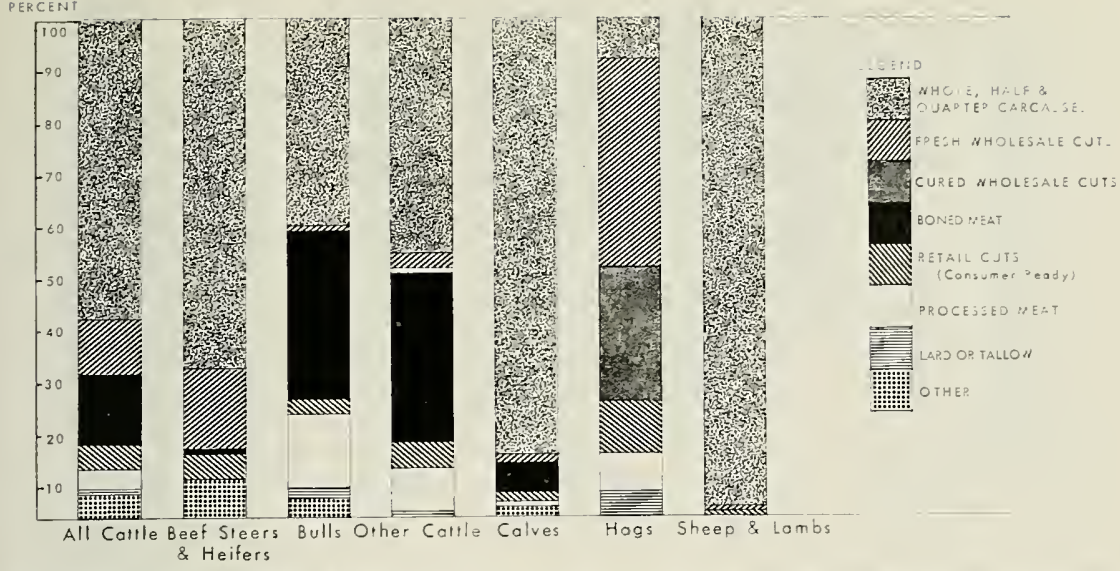

FIGURE 10. Carcass Breakdown by Kind of Livestock Slaughtered, Northeastern Slaughter Plant Sample, 1955.

many of the slaughterers use the meat from lower grade animals in preparing processed meats.

Of the animals slaughtered in sample Northeastern slaughtering establishments during 1955, 60 per cent of the cattle, 87 per cent of the calves, 8 per cent of the hogs, and 98 per cent of the lambs were sold as whole, half, or quarter carcasses (Figure 10). Approximately 70 per cent of the pork carcasses were broken down into wholesale cuts and sold as fresh or cured cuts. Although boned meat accounted for only 14 per cent of the cattle, most of it came from dairy cattle and bulls. Considerable

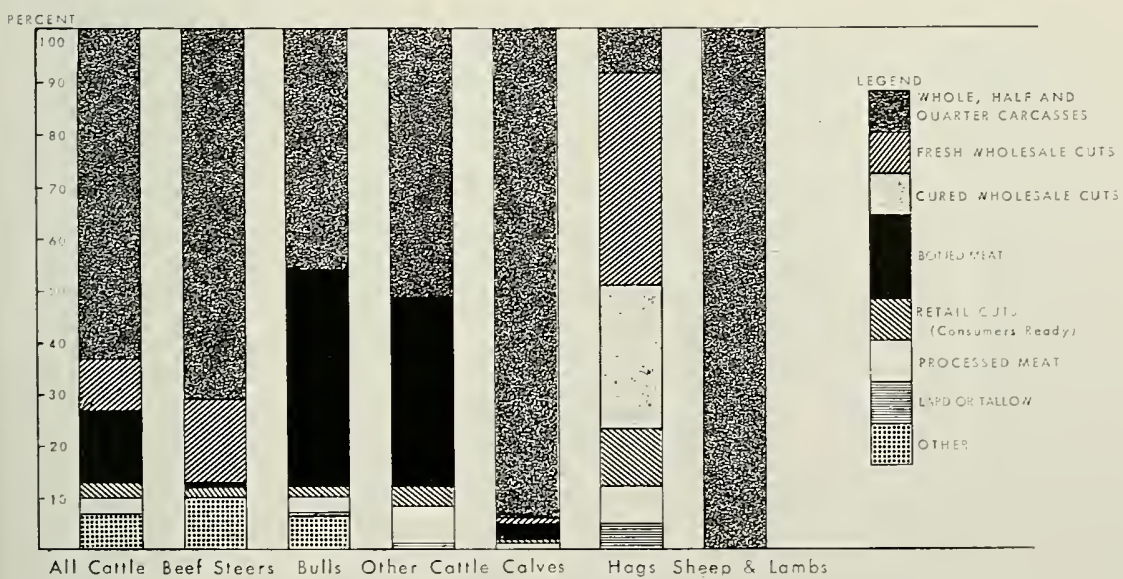
$\&$ Heifers

FIGURE 11. Carcass Breakdown by Kind of Livestock Slaughtered, Northeastern Federally Inspected Slaughter Plants, 1955. 


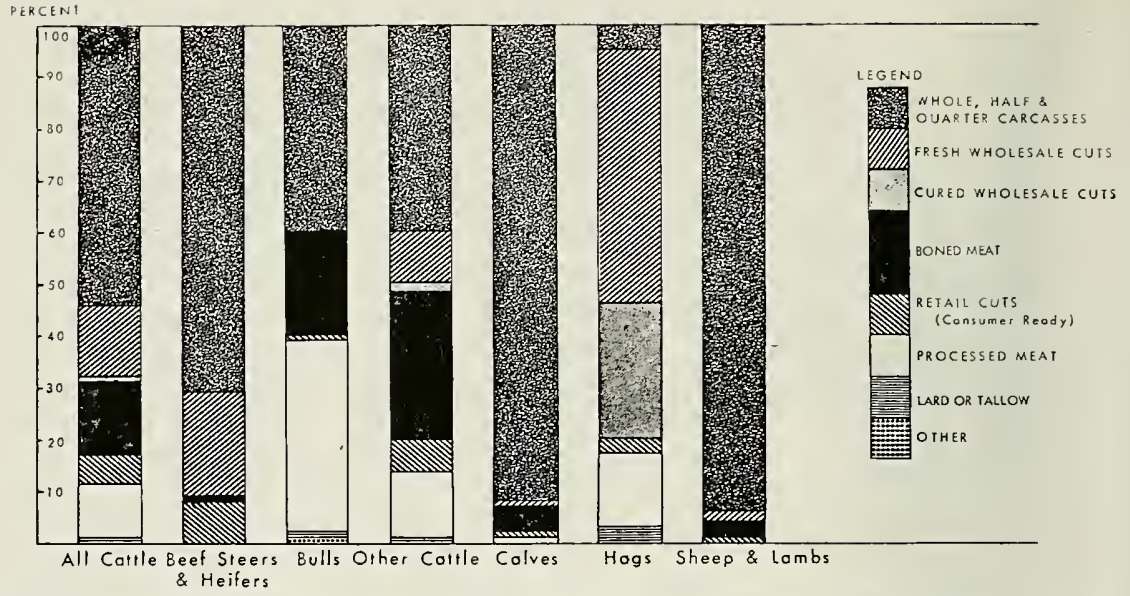

FIGURE 12. Carcass Breakdown by Kind of Livestock Slaughtered, Northeastern Wholesale Slaughter Plants, 1955.

amounts of the meat from each kind of meat animals were sold in other breakdown forms, but none of these accounted for more than 10 per cent of the total meat from any kind of meat animal.

The primary difference in carcass breakdown among federally inspected, wholesale and local slaughtering plants is in the proportion of meat sold in different forms. The major proportion of all meat animals slaughtered is sold in whole, half, or quarter carcass form. Federally inspected plants sell the highest proportion in this form, wholesale plants

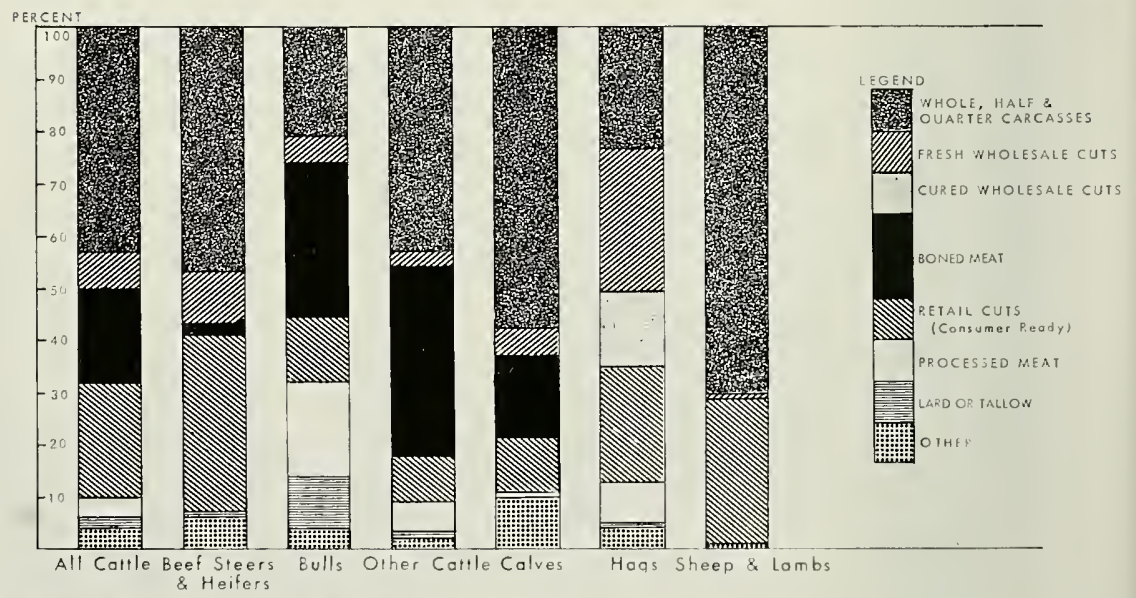

FIGURE 13. Carcass Breakdown by Kind of Livestock Slaughtered, Northeastern Local Slaughter Plants, 1955. 
rank second, and local plants rank third (Figures 11, I2, and 13). Betreen wholesale and federally inspected plants there is little difference in the proportion of meat sold in each form. However, with each kind of meat animal local slaughterers sell a larger proportion of their meat as retail cuts than do wholesale and federally inspected slaughterers. Local plants also sell a larger proportion of their meat as boned meat than do wholesale or lederally inspected plants.

\section{Federally Graded Meat}

Grading of neat by Federal graders is an operation which is becoming increasingly more important. Several factors are contributing to this increased emphasis upon Federal grading, but consumers and retail-chain stores are quite likely providing the major stimuli.

Consumers, either through educational enlightenment on Federal grades by published literature or through exposure and subsequent positive reaction to large-scale advertising, have increased their demand for federally graded and stamped meat. Very likely there is a sense of security, among other things, associated with buying meat that has been icderally graded.

Over the years, retail chain stores have increased their economic influence considerably. Along with this economic influence, they have encouraged federal grading by their advertising and meat-buying policies. How much influence meat advertisements such as "United States Federally Inspected and Graded" have on purchasing habits of consumers is not known, but it has had a profound effect on the type of meat bought and sold by large retailing organizations.

With the exception of beef, very little of the meat originating in Northeastern slaughter plants is federally graded. Of the total meat from animals slaughtered in sample plants during 1955, approximately 34 per cent of the beef, 7 per cent of the veal, 10 per cent of the pork, and 9 per cent of the lamb was feclerally graded. As indicated in Table 15 federal grading of beef is largely restricted to the meat from beef steers and heifers.

Federal grading is a service for which slaughterers must pay, and therefore it is reasonable to assume they will restrict fecleral grading to those carcasses which they expect to resell at a price which will cover the cost of grading in addition to other costs. This does not mean, however, that the cost of Federal grading for particular carcasses will always be recovered. In addition, lower quality carcasses which are used printarily in the manufacture of sausage, meat loaves, canned and other processed meats are not usually graded. Therefore, in practice, slaughterers confine Federal grading to the higher quality carcasses. 
In general, only a small proportion of the meat animals produced in the Northeastern region have the necessary attributes to be graded in the upper two or three Federal grades of meat. We can, therefore, expect that only a small amount of the meat produced in the region will be federally graded. A majority of the slaughter steers and heifers, however, are sinipped into the region and these animals possess those characteristics necessary to be placed in the higher grades. As a result, a large proportion of the steer and heifer carcasses are federally graded.

Among the federally inspected, wholesale, and local slaughtering plants there is a wide difference in the use of Federal grading (Table 15). Federally inspected plants sold more federally graded meat than did wholesale plants, while local plants sold no federally graded meat. No attempt was made to determine why slaughterers do or do not use this service. However, the relatively low volume and lower quality meat in most wholesale and local plants probably accounts for the low percentage of federally graded meat by these plants.

Table 15. Amount of Meat Federally Graded in Northeastern Slaughter Plant Sample, 1955

\begin{tabular}{|c|c|c|c|c|}
\hline $\begin{array}{c}\text { Plant } \\
\text { CrassifICATION }\end{array}$ & $\begin{array}{l}\text { KIND OF } \\
\text { LIVESTOCK }\end{array}$ & $\begin{array}{c}\text { TOTAL POUNDS OF } \\
\text { DRESSED MEAT }\end{array}$ & $\begin{array}{c}\text { TOTAL POUNDS OF } \\
\text { MEAT FEDERALLY } \\
\text { GRADED }\end{array}$ & $\begin{array}{c}\text { Per Cent of } \\
\text { Meat Federally } \\
\text { Graded }\end{array}$ \\
\hline $\begin{array}{l}\text { All } \\
\text { Plants } \\
\text { in the } \\
\text { Sample }\end{array}$ & $\begin{array}{l}\text { All Cattle } \\
\text { Strs. \& Heifers } \\
\text { Bulls } \\
\text { Other Cattle } \\
\text { Calves } \\
\text { Hogs } \\
\text { Sheep \& Lambs }\end{array}$ & $\begin{array}{r}561,819,051 \\
329,898,082 \\
35,769,286 \\
196,151,683 \\
77,782,498 \\
497,384,372 \\
49,101,514\end{array}$ & $\begin{array}{r}182,952,580 \\
182,394,289 \\
2,113,730 \\
5,444,561 \\
5,390,354 \\
50,418,400 \\
4,434,849\end{array}$ & $\begin{array}{r}34 \\
35 \\
6 \\
3 \\
7 \\
10 \\
9\end{array}$ \\
\hline $\begin{array}{l}\text { Federally } \\
\text { Inspected }\end{array}$ & $\begin{array}{l}\text { All Cattle } \\
\text { Strs. \& Heifers } \\
\text { Bulls } \\
\text { Other Cattle } \\
\text { Calves } \\
\text { Hogs } \\
\text { Sheey \& Lambs }\end{array}$ & $\begin{array}{r}414,530.979 \\
261,249,812 \\
21,490,848 \\
131,790,319 \\
32,400,999 \\
408,754,319 \\
43,007,841\end{array}$ & $\begin{array}{r}187,034,830 \\
179,721,272 \\
1,988,828 \\
5,324,730 \\
5.245,814 \\
50,418,400 \\
4,403,785\end{array}$ & $\begin{array}{r}45 \\
69 \\
9 \\
4 \\
16 \\
12 \\
10\end{array}$ \\
\hline Wholesale & $\begin{array}{l}\text { All Cattle } \\
\text { Strk \& Heifers } \\
\text { Bulls } \\
\text { Other Cattle } \\
\text { Calves } \\
\text { Hogs } \\
\text { Sheep \& Lambs }\end{array}$ & $\begin{array}{r}114,153,856 \\
51,955,652 \\
11,211,915 \\
50,986,289 \\
: 32,394,115 \\
77,498,714 \\
4,654,327\end{array}$ & $\begin{array}{r}2,917,750 \\
2.673,017 \\
124,902 \\
119,831 \\
144,540 \\
0 \\
31,064\end{array}$ & $\begin{array}{l}8 \\
5 \\
1 \\
* \\
* \\
0 \\
1\end{array}$ \\
\hline Local & $\begin{array}{l}\text { All Cattle } \\
\text { Strs, \& Heifers } \\
\text { Bulls } \\
\text { Other Cattle } \\
\text { Calves } \\
\text { Hogs } \\
\text { Sheep \& Lambs }\end{array}$ & $\begin{array}{r}33,134,216 \\
16,692,618 \\
3,066,523 \\
13,375,075 \\
12,987,384 \\
11,131,339 \\
1,439,346\end{array}$ & $\begin{array}{l}0 \\
0 \\
0 \\
0 \\
0 \\
0 \\
0\end{array}$ & $\begin{array}{l}0 \\
0 \\
0 \\
0 \\
0 \\
0 \\
0\end{array}$ \\
\hline
\end{tabular}

* Less than .005. 


\begin{tabular}{|c|c|c|c|}
\hline \multirow[b]{2}{*}{ EXPERIENCE } & \multicolumn{3}{|c|}{ Plant Classification (Responses) } \\
\hline & $\begin{array}{l}\text { FEDERALLY } \\
\text { 1NSPECTED }\end{array}$ & WHOLESALE & LOCAL \\
\hline Not consistent & 2 & - & - \\
\hline Good law, poor administration ........ & 2 & 1 & 1 \\
\hline No experience ..................................................... & 3 & - & - \\
\hline Aids sales and gives security on market & 8 & 5 & 6 \\
\hline Satisfactory _. & 14 & 21 & 17 \\
\hline Fair grading & 6 & - & - \\
\hline Used during war only & 3 & 6 & 25 \\
\hline Unnecessary ...... & - & - & 7 \\
\hline Too expensive ............ & - & $\tau$ & 16 \\
\hline Unsatisfactory & - & 1 & 5 \\
\hline Inexperienced graders & - & 1 & 14 \\
\hline Inconvenient & - & 1 & 5 \\
\hline No eflect on business & - & 2 & - \\
\hline Aids only in high grades & — & 1 & - \\
\hline
\end{tabular}

An effort was made to determine how slaughterers felt about Federal grading by asking "What has been your experience with Federal grading?" The responses to this question indicate that a majority of those using Federal grading were satisfied with the service, while those not using it tended to find fault with it (Table 16). Local slaughterers, although not using Federal grading, tended to be the most dissatisfied with it.

\section{Disposition of Livestock By-Products}

Markets for livestock by-products are very important in determining prices received by livestock producers, and prices paid by consumers for meat and meat products. Without the revenues from hides, bones, tallow, lard, glands, and other edible and inedible offal, slaughterers would pay less for livestock or charge more for meat and meat products or a combination of both.

The utilization of by-products is very complete with almost no parts of an animal being discarded. In the past, it was often stated that everything but the hog's squeal was sold by slaughterers. The data in Tables 17 , 18, and 19 indicate that this is largely correct, as very few plants discard any by-products.

Some of the more important outlets used by Northeastern slaughter plants for disposing of livestock by-products are rendering plants, tanneries or hide companies, feed and fertilizer companies, soap manufacturers, and drug and tallow companies. Several of the plants sell their by-products to dealers, brokers, and jobbers who, in turn, sell them to these companies. Another group of slaughterers do some processing of byproducts such as rendering, salting, curing and cooking before clisposing of them. 
Table 17. Disposition of Livestock By-Products, Northeastern Federally Inspreted Slaughter Plants, 1955

\begin{tabular}{|c|c|c|c|c|}
\hline \multirow[b]{2}{*}{ METHODS OF DISPOSAL USED } & \multicolumn{4}{|c|}{$\begin{array}{l}\text { By-Products and Number of Plants } \\
\text { Reporting Method of Disposal Used }\end{array}$} \\
\hline & BONES & Hides & TALLOW & $\begin{array}{c}\text { OTHER } \\
\text { INEDIBLE } \\
\text { OFFAL }\end{array}$ \\
\hline Dealers & \multirow{15}{*}{$\begin{array}{r}2 \\
22 \\
2 \\
2 \\
8 \\
5 \\
1 \\
1 \\
2\end{array}$} & \multirow{9}{*}{$\begin{array}{l}2 \\
5 \\
1\end{array}$} & \multirow{15}{*}{$\begin{array}{r}2 \\
21 \\
1 \\
1 \\
8 \\
1 \\
1\end{array}$} & 2 \\
\hline Rendering Plants & & & & 20 \\
\hline 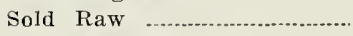 & & & & 1 \\
\hline Feed Manufacturers ................. & & & & 3 \\
\hline 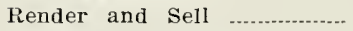 & & & & 10 \\
\hline Tankage & & & & 1 \\
\hline Jobbers & & & & 2 \\
\hline Fertilizer Companies ........... & & & & 1 \\
\hline Discarded & & & & 1 \\
\hline Brokers & & \multirow{6}{*}{$\begin{array}{r}11 \\
12 \\
5\end{array}$} & & \\
\hline Dog and Mink Farms ............. & & & & 3 \\
\hline Soap Companies & & & & \\
\hline Salt and Sell & & & & \\
\hline Tanneries - & & & & \\
\hline Hide Companies & & & & \\
\hline
\end{tabular}

Rendering plants are the most important outlets for all by-products except hides. Tanneries, hide, and leather companies purchase most of the hides. From the number of outlets listed by these slaughter plants and the small number of plants discarding by-products (Tables 17, 18, and 19) one can assume that there is little difficulty in disposing of by-products.

\section{Table 18. Disposition of Livestock By-Products, Northeastern Wholesale Slaughter Plants, 1955}

\begin{tabular}{|c|c|c|c|c|}
\hline \multirow[b]{2}{*}{ Methods of Disposal Used } & \multicolumn{4}{|c|}{$\begin{array}{l}\text { By-Products and Number of Plants } \\
\text { Reporting Method of Disposal Used }\end{array}$} \\
\hline & BONES & HIDES & TALLOW & $\begin{array}{l}\text { OTHER } \\
\text { INEDIBLE } \\
\text { OFFAL }\end{array}$ \\
\hline \multirow{2}{*}{ 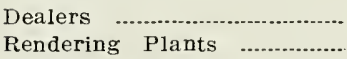 } & \multirow{19}{*}{$\begin{array}{r}6 \\
42 \\
1 \\
3 \\
1 \\
2 \\
3 \\
11\end{array}$} & \multirow{8}{*}{$\begin{array}{r}11 \\
5 \\
6 \\
1 \\
1\end{array}$} & \multirow{19}{*}{$\begin{array}{r}5 \\
27 \\
10 \\
1 \\
2 \\
1 \\
13 \\
2 \\
3 \\
6 \\
2 \\
2\end{array}$} & 5 \\
\hline & & & & 34 \\
\hline 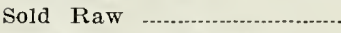 & & & & 9 \\
\hline Fertilizer Companies ........... & & & & 2 \\
\hline Tallow Companies ............. & & & & 1 \\
\hline Feed Manufacturers & & & & 1 \\
\hline Rendering and Sell & & & & 3 \\
\hline Tankage & & & & 8 \\
\hline Hide Companies ........................ & & \multirow{11}{*}{$\begin{array}{l}21 \\
12 \\
17\end{array}$} & & 1 \\
\hline Soap Companies ………............ & & & & 1 \\
\hline Jobbers & & & & 1 \\
\hline Cook and Feed Hogs............ & & & & \\
\hline Salt and Sell & & & & \\
\hline Brokers & & & & \\
\hline Tanneries & & & & \\
\hline Salterers & & & & \\
\hline Cure & & & & \\
\hline $\begin{array}{l}\text { Dog and Mink Farms } \\
\text { Drug Companies }\end{array}$ & & & & $\begin{array}{l}7 \\
3\end{array}$ \\
\hline Discarded & & & & 5 \\
\hline
\end{tabular}


Between the plant classes there does not appear to be any great difference in the market outlets used for disposing of by-products.

Table 19. Disposition of Livestock By-Products, Northeastern Local Slaughthr Plants, 1955

\begin{tabular}{|c|c|c|c|c|}
\hline \multirow[b]{2}{*}{ Method of Disposal Used } & \multicolumn{4}{|c|}{$\begin{array}{l}\text { By-Products and Number of Plants } \\
\text { Reporting Method of Disposal Used }\end{array}$} \\
\hline & BONES & HIDES & TALLOW & $\begin{array}{c}\text { OTHER } \\
\text { INEDIBLE } \\
\text { OFFAL }\end{array}$ \\
\hline Rendering Plants & \multirow{22}{*}{$\begin{array}{r}70 \\
21 \\
32 \\
6 \\
2 \\
2 \\
3 \\
\\
\\
2 \\
1 \\
1 \\
2\end{array}$} & \multirow{22}{*}{$\begin{array}{r}40 \\
35 \\
16 \\
11 \\
1 \\
2 \\
\\
1 \\
1\end{array}$} & \multirow{10}{*}{$\begin{array}{r}61 \\
23 \\
17 \\
6 \\
3 \\
2 \\
2 \\
1 \\
1\end{array}$} & \multirow{2}{*}{$\begin{array}{l}53 \\
18\end{array}$} \\
\hline Hide and Tallow Company & & & & \\
\hline Sold Raw & & & & \multirow{2}{*}{26} \\
\hline Dealers & & & & \\
\hline Fertilizer Companies & & & & 4 \\
\hline Fat Company & & & & \multirow{2}{*}{$\begin{array}{l}2 \\
4\end{array}$} \\
\hline Tankage ........................... & & & & \\
\hline Packing Plant ............................ & & & & \multirow[t]{2}{*}{1} \\
\hline Brokers & & & & \\
\hline Cooked and Fed to Hogs -- & & & & \multirow{10}{*}{$\begin{array}{l}3 \\
1\end{array}$} \\
\hline Soap Companies ..................... & & & & \\
\hline Sell to Farmers & & & & \\
\hline Feed Manufacturers ............... & & & & \\
\hline Given to Customers & & & & \\
\hline Salt and Sell ........................... & & & & \\
\hline Tanneries ……………................ & & & & \\
\hline Cure & & & & \\
\hline Fed to Hogs & & & \multirow{5}{*}{$\begin{array}{l}2 \\
4\end{array}$} & \\
\hline Render and Sell ................... & & & & \\
\hline Mink or Dog Farms & & & & 13 \\
\hline Discarded & & & & 8 \\
\hline Drug Companies …….............. & & & & 2 \\
\hline
\end{tabular}




\section{APPENDIX A}

\section{Sampling Procedure}

With the exception of Maine, Vermont and Massachusetts, the sampling rate was one half of the federally inspected plants, one third of the wholesale plants and one fourth of the local plants. In Maine, Vermont, and Massachusetts, the sample was enlarged to include all of the federally inspected and wholesale slaughter plants to insure a representative sample.

On the basis of commercial livestock slaughter statistics, the combined slaughter of all plants in the sample represents 41 per cent of the cattle slaughtered in the Northeast, 34 per cent of the calves, 34 per cent of the hogs, and 37 per cent of the sheep and lambs. ${ }^{1}$ Another check is made on the sample by expanding the sample data and comparing it to the USDA commercial slaughter figures for 1955 (Table 1). When these adjustments are made, there is approximately 5 per cent difference in the number of cattle, 8 per cent in calves, 19 per cent in hogs and 20 per cent in sheep and lambs. The large differences in hogs, sheep and lambs is likely due to the uncooperativeness of a few large federally inspected slaughter plants in the Boston area. Even so, it is remarkable that the volume of livestock slaughtered by a sample based entirely on number of plants would be so close (after adjustments) to the reported slaughter figures for the region.

"The following data for 1955 was compiled from Livestock Market News Statisties anul Lelated Dat $\iota, 1956$, USDA, AMS, Livestock Division, Statistical Bulletin 209, June 1957, p. 29 , and from data obtained in the sample survey.

\begin{tabular}{|c|c|c|c|}
\hline & $\begin{array}{c}\text { Total Regional } \\
\text { SLAUGHTER (HEAd) }\end{array}$ & $\begin{array}{l}\text { Total Slaughter } \\
\text { in Sample (Head) }\end{array}$ & $\begin{array}{l}\text { Sample Slaughter } \\
\text { as a Per Cent of } \\
\text { Regional Slaughter }\end{array}$ \\
\hline Cattle & $2,393,000$ & 979,576 & $41 \%$ \\
\hline Calves & $3,041,000$ & $1,023,870$ & $34 \%$ \\
\hline Hogs & $8,195,000$ & $3,030,467$ & $34 \%$ \\
\hline Sheep \& Lambs & $3,069,000$ & $1,145,473$ & $37 \%$ \\
\hline
\end{tabular}




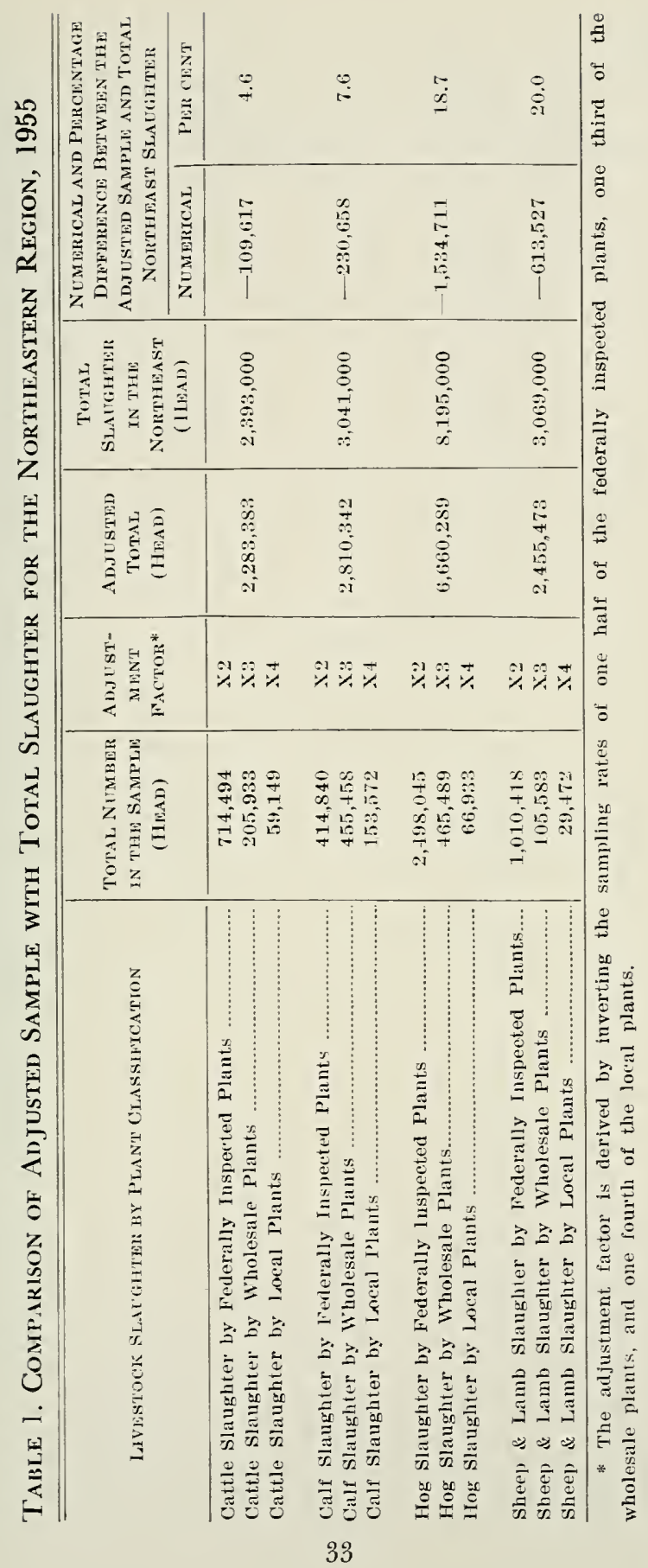




\section{APPENDIX B}

Table 1. Average Live Weight, Average Dressed Weight and Dressing Percentage for Cattle, Calves, Hogs, Sheep and Lambs, United States, 1945 Through 1955

\begin{tabular}{|c|c|c|c|}
\hline YEAR & $\begin{array}{c}\text { AVERAGE } \\
\text { LIVE WEIGHT } \\
\text { (POUNDS) }\end{array}$ & $\begin{array}{c}\text { AVERAGE } \\
\text { DRESSED WEIGHT } \\
\text { (POUNDS) }\end{array}$ & $\begin{array}{l}\text { DRESSing } \\
\text { PERCENTAGe } \\
\text { (Pounds) }\end{array}$ \\
\hline
\end{tabular}

\section{Cattle}

1945

1946

1947

1948

1949

1950

1951

1952

1953

1954

1955

947.5

942.7

927.5

944.6

976.4

989.1

992.2

990.2

969.8

958.2

975.0

500.5
499.1
488.0
497.7
531.8
540.8
544.3
546.0
533.1
526.3
537.2

52.8

52.9

52.6

52.7

54.5

54.7

54.9

55.1

55.0

54.9

55.1

Average : $\overline{54.1}$

\section{Calves}

1945

1946

1947

1948

1949

1950

1951

1952

1953

1954

1955

213.9

199.4

208.6

208.6

209.4

206.0

209.2

220.6

226.7

223.0

217.7
118.0

110.8

114.7

115.2

116.3

114.7

117.6

123.5

126.2

123.6

121.0
55.2

55.6

55.0

55.2

55.5

55.7

56.2

56.0

55.7

55.4

55.6

Average : 55.6

$\begin{array}{ll}\text { Hogs } & \\ 1945 & 264.6 \\ 1946 & 254.7 \\ 1947 & 253.9 \\ 1948 & 252.9 \\ 1949 & 247.6 \\ 1950 & 244.4 \\ 1951 & 245.8 \\ 1952 & 242.6 \\ 1953 & 238.4 \\ 1954 & 243.9 \\ 1955 & 240.8\end{array}$

75.8

75.3

75.9

76.0

76.2

75.9

75.2

75.8

76.3

76.7

76.5

Average : $\overline{76.0}$

Source: Compiled from Livestock Market News Statistics and Related Data, 1954 and 1956, Statistical Bulletins Nos. 162 and 209, dated June 1952 and June 1957 respectively. ¿SDA, AMS, Livestock Division. 
Table 1 (Gont'd)

\begin{tabular}{|c|c|c|c|}
\hline YEAR & $\begin{array}{c}\text { Average } \\
\text { LTVE Weight }\end{array}$ & $\begin{array}{c}\text { AVERAGE } \\
\text { DRESSED WeIGHT } \\
\text { (PoUNDS) }\end{array}$ & $\begin{array}{c}\text { Dressing } \\
\text { Percentage }\end{array}$ \\
\hline \multicolumn{4}{|c|}{ Sheep and Lambs } \\
\hline 1945 & 94.4 & 43.2 & 45.8 \\
\hline 1946 & 93.7 & 42.9 & 45.8 \\
\hline 1947 & 93.6 & 43.2 & 46.2 \\
\hline 1948 & 94.4 & 43.6 & 46.2 \\
\hline 1949 & 94.1 & 44.3 & 47.1 \\
\hline 1950 & 96.1 & 45.7 & 47.6 \\
\hline 1951 & 98.3 & 46.6 & 47.4 \\
\hline 1952 & 97.5 & 46.0 & 47.2 \\
\hline 1953 & 95.3 & 45.3 & 47.5 \\
\hline 1954 & 95.7 & 45.8 & 47.9 \\
\hline \multirow[t]{2}{*}{1955} & 96.4 & 46.3 & 48.0 \\
\hline & & & Average $: \overline{47.0}$ \\
\hline
\end{tabular}




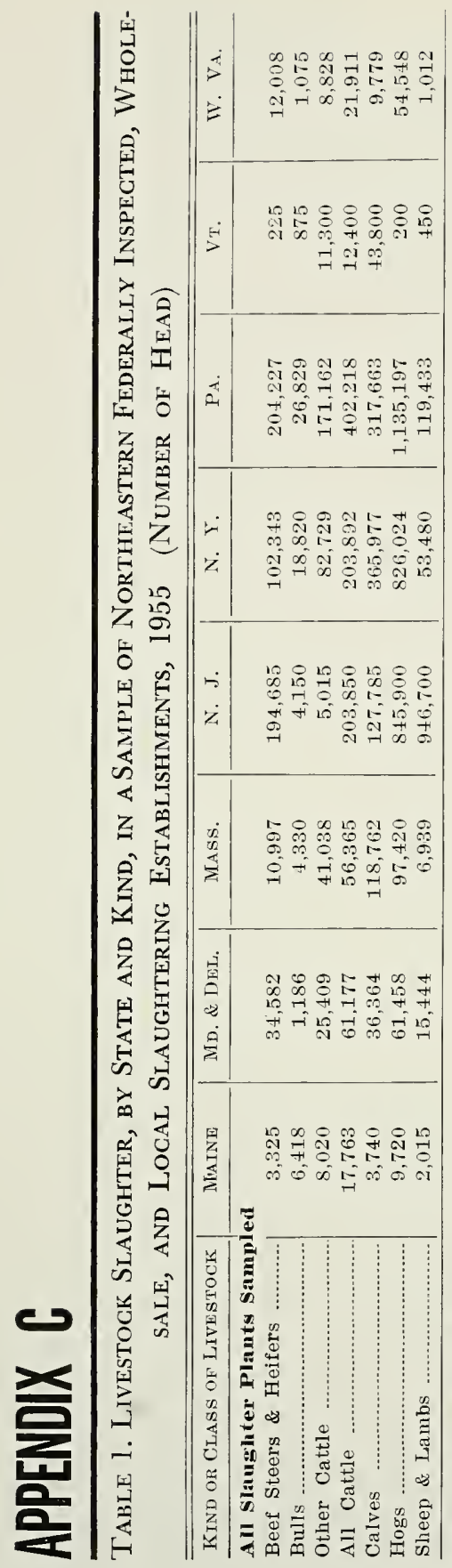

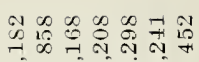

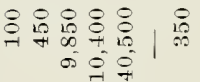

10

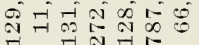

HODNON N

ถึ

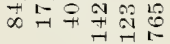

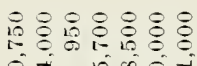

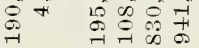

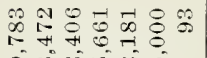

क 02 ถู

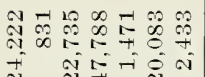

ते ลैन

$\stackrel{2}{*}$

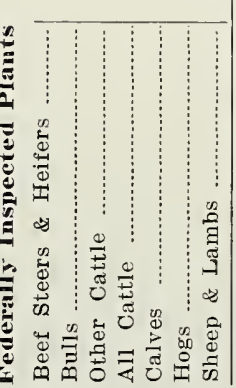

$0_{-1}^{-\infty} \infty \overbrace{-1}^{\infty}$

党 ता

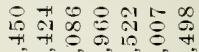
18

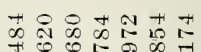

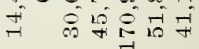

은,

a बा को की 10

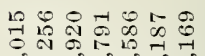
ति

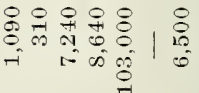

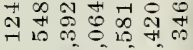
तi को क

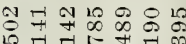
की को की की

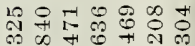
ल न न

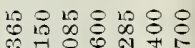
- 7 तो

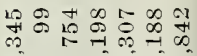
का से क्ष

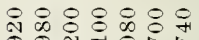
$-100+$ of

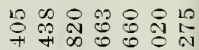

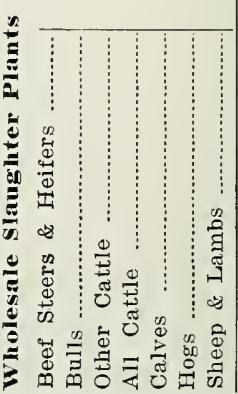

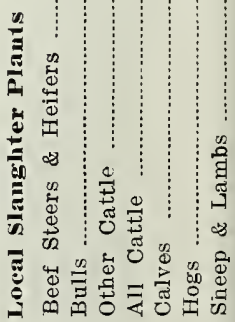




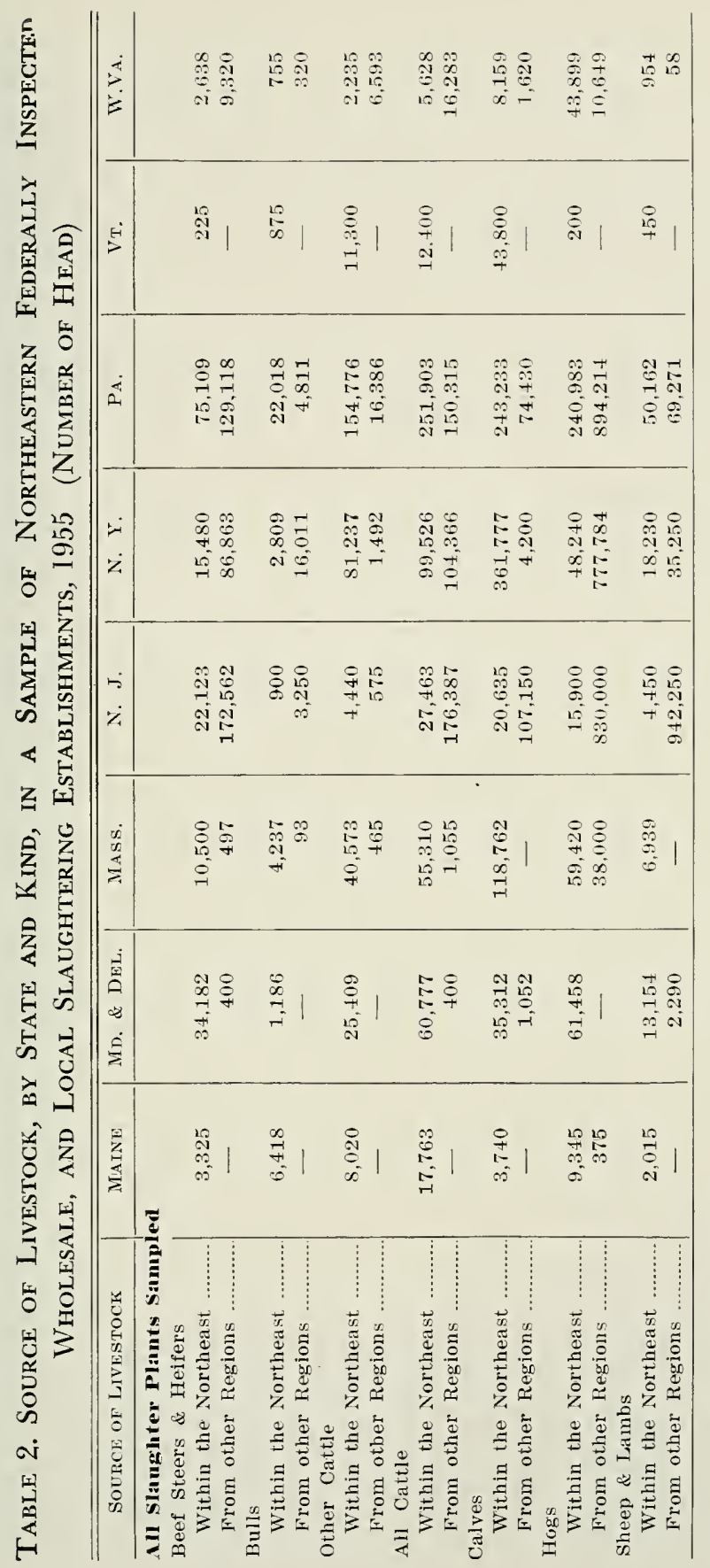

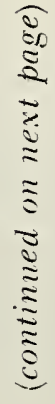




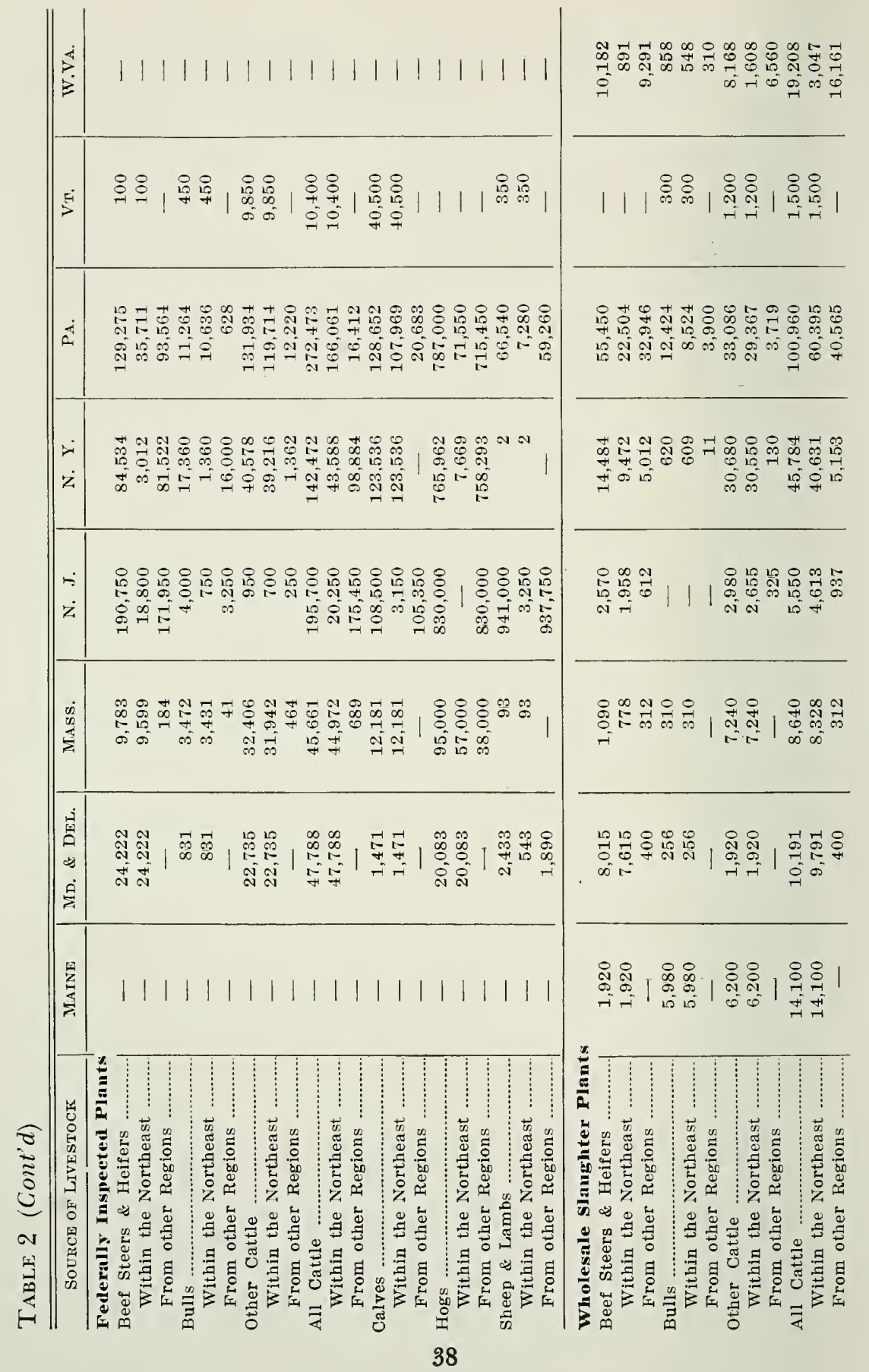




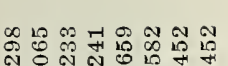
年

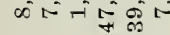

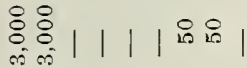

in $\infty$ ก m 0 \% म

i क म है

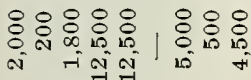

盟

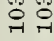

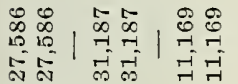

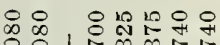
ल

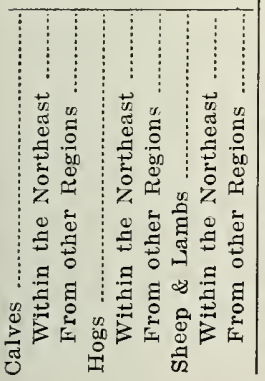

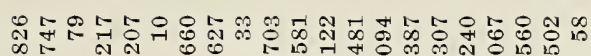

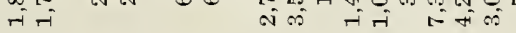

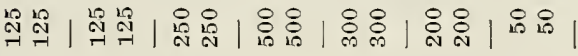

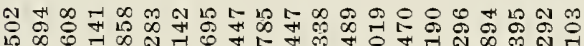
O.

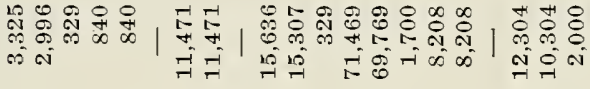

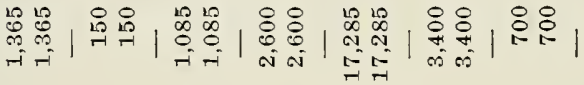

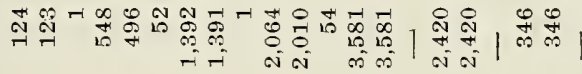

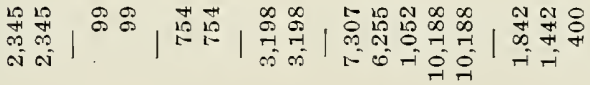

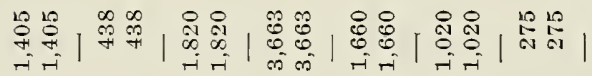

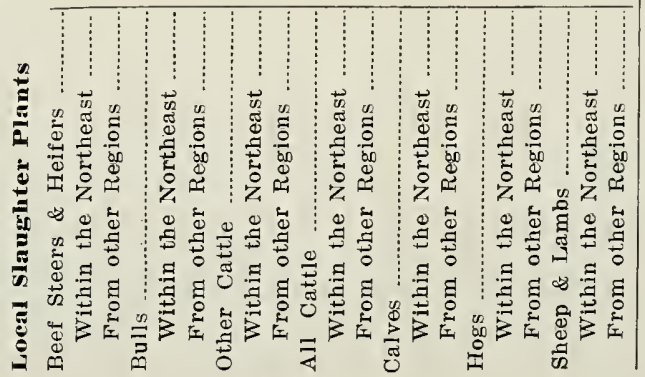




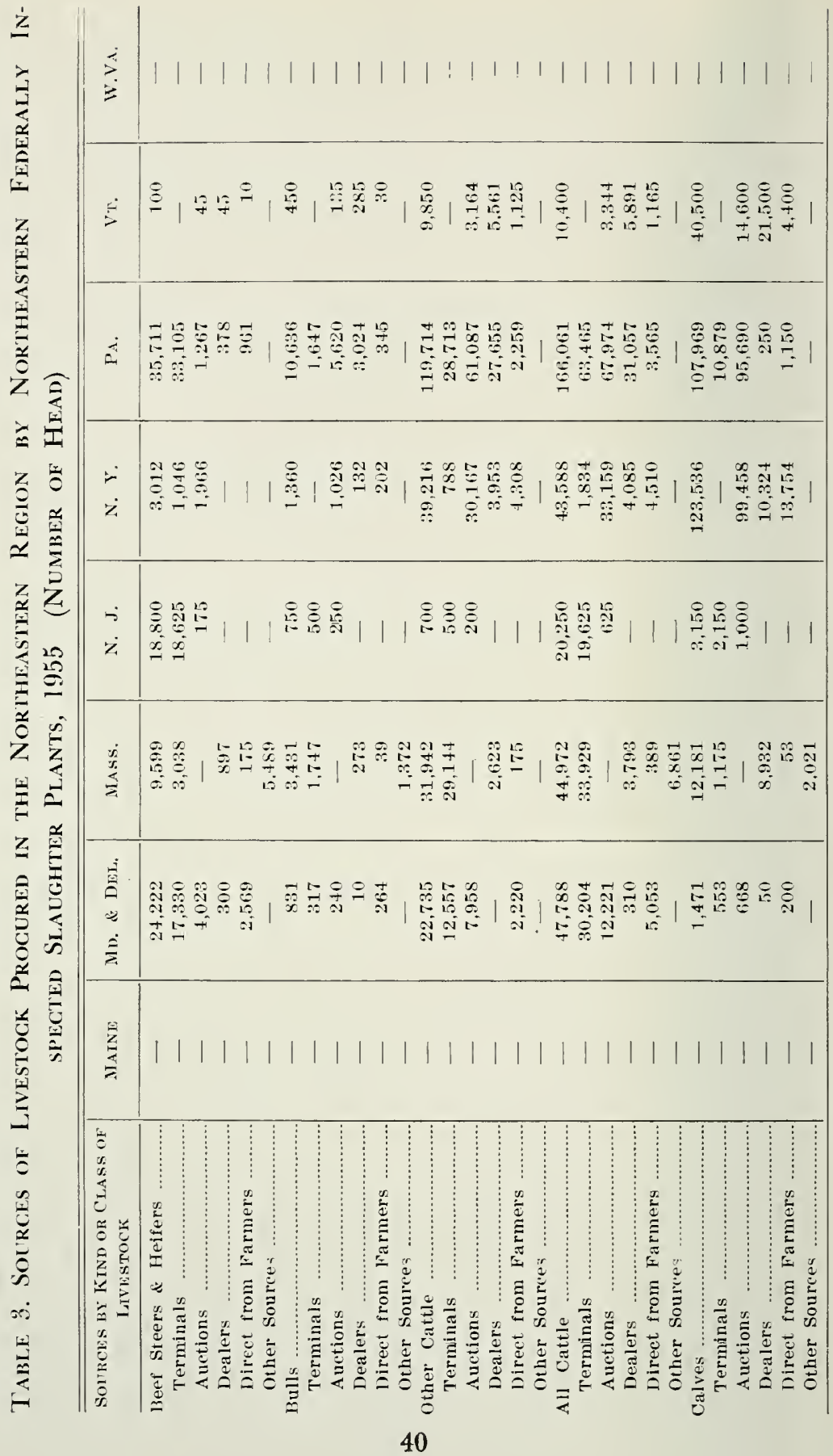




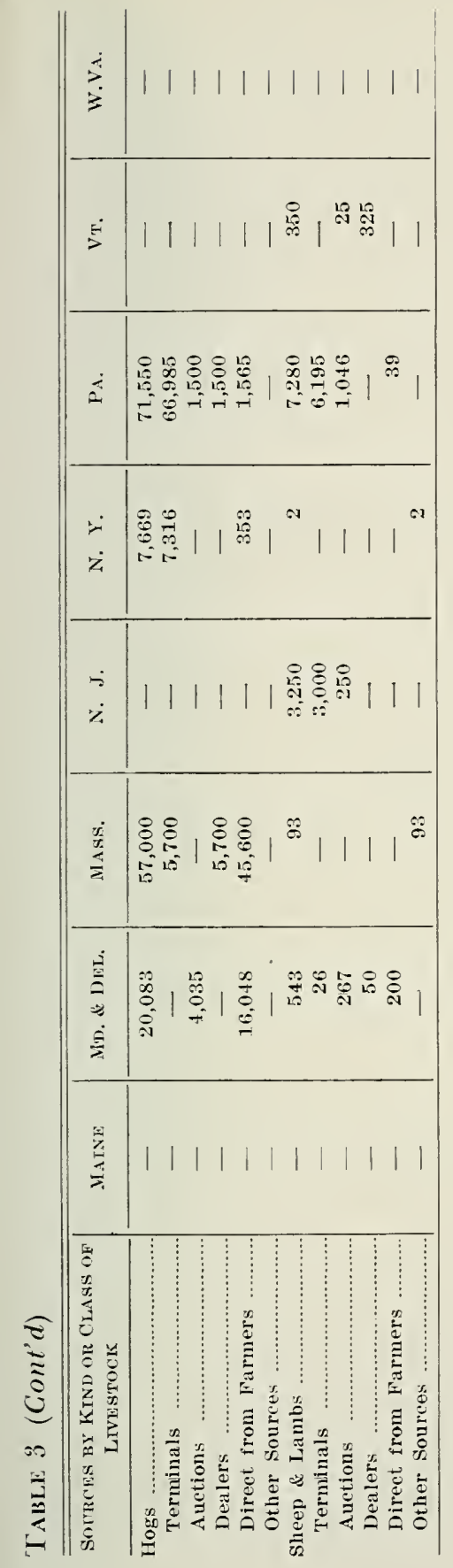




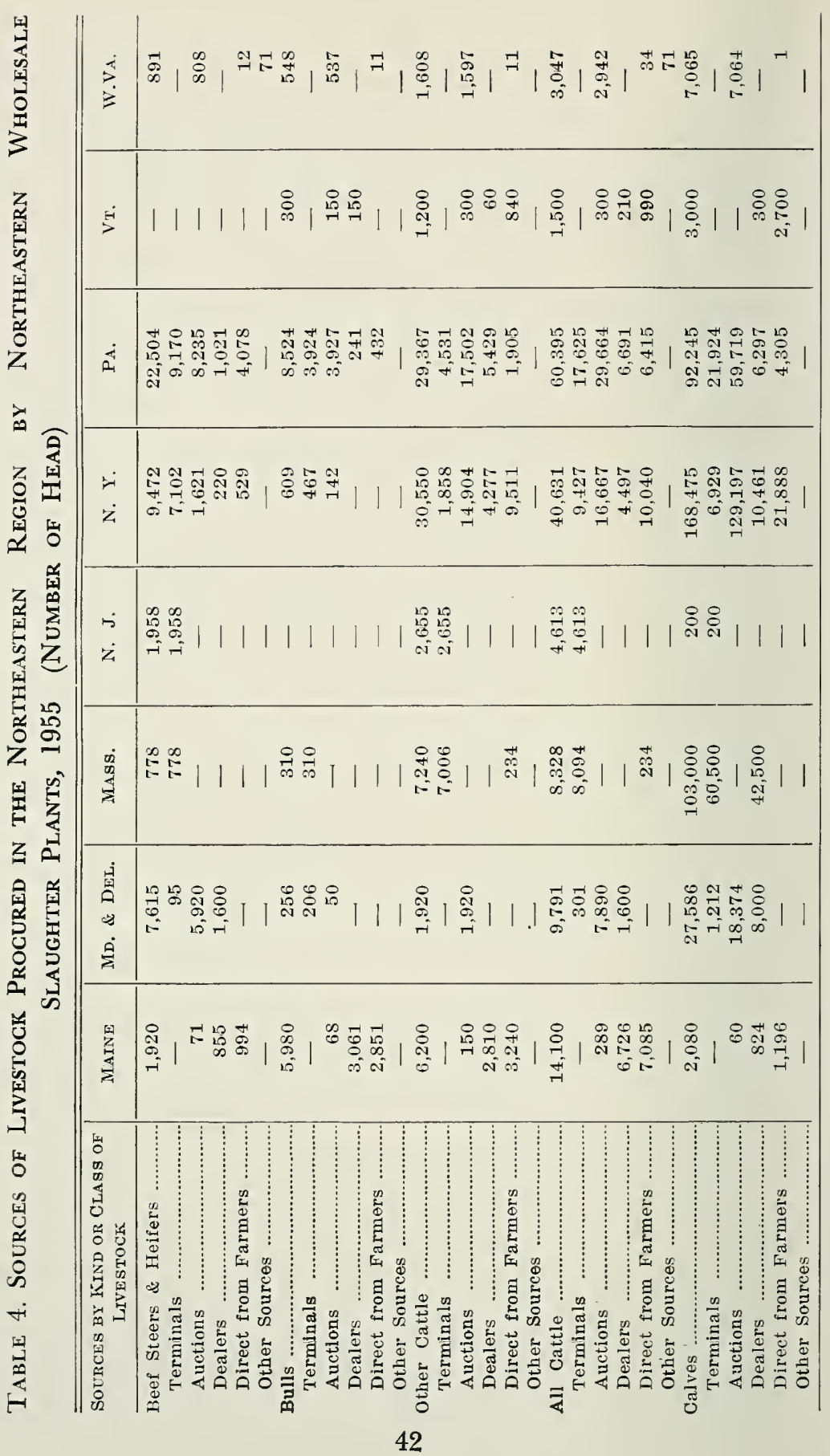




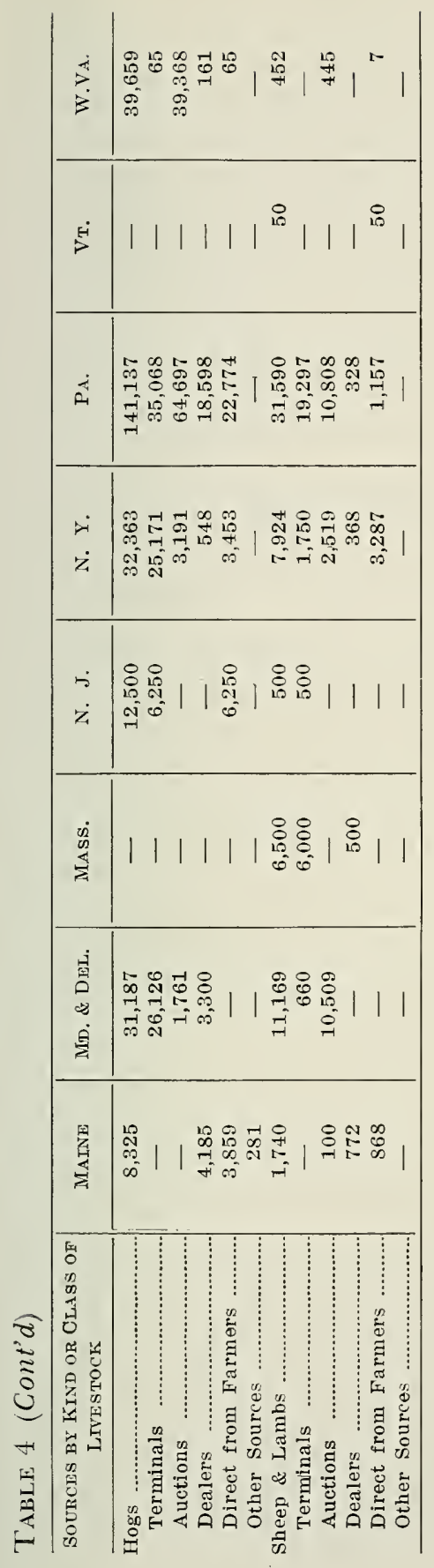




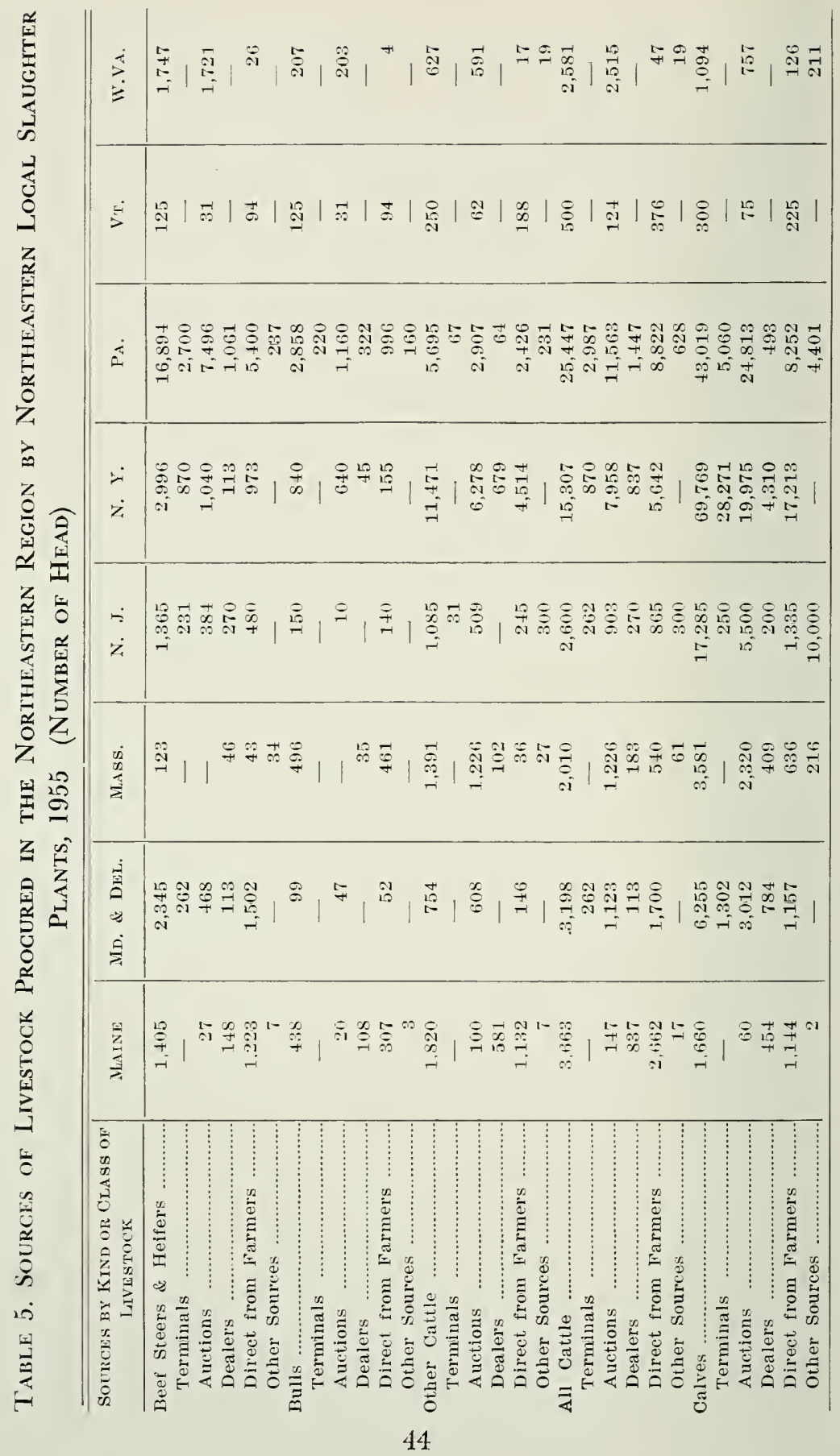




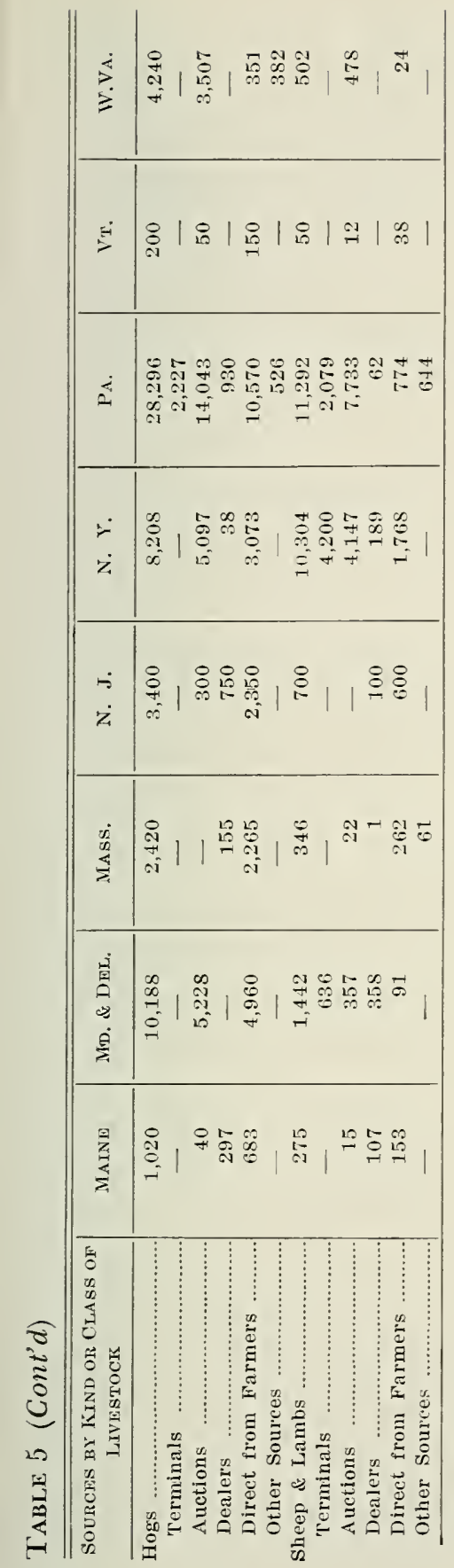




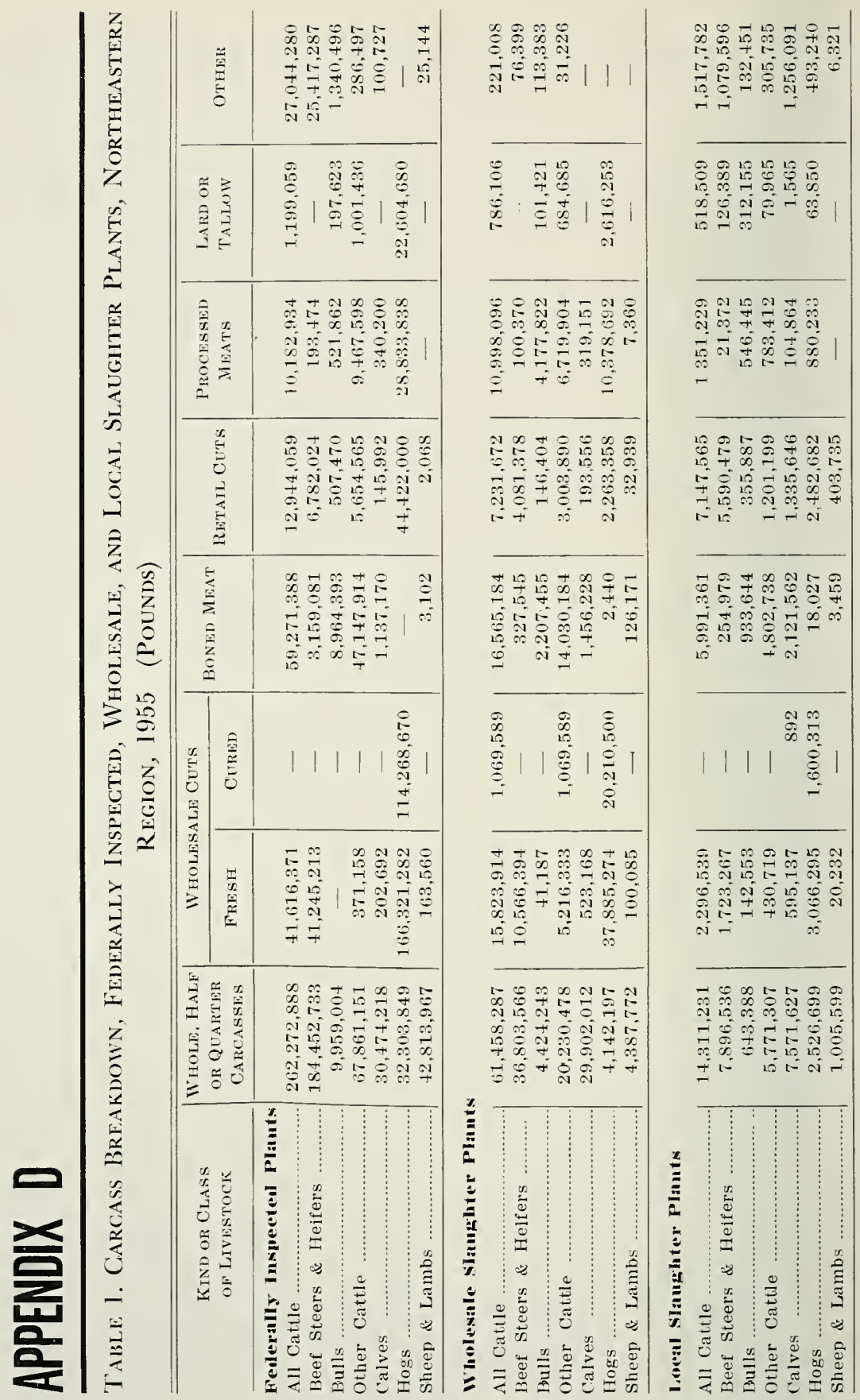




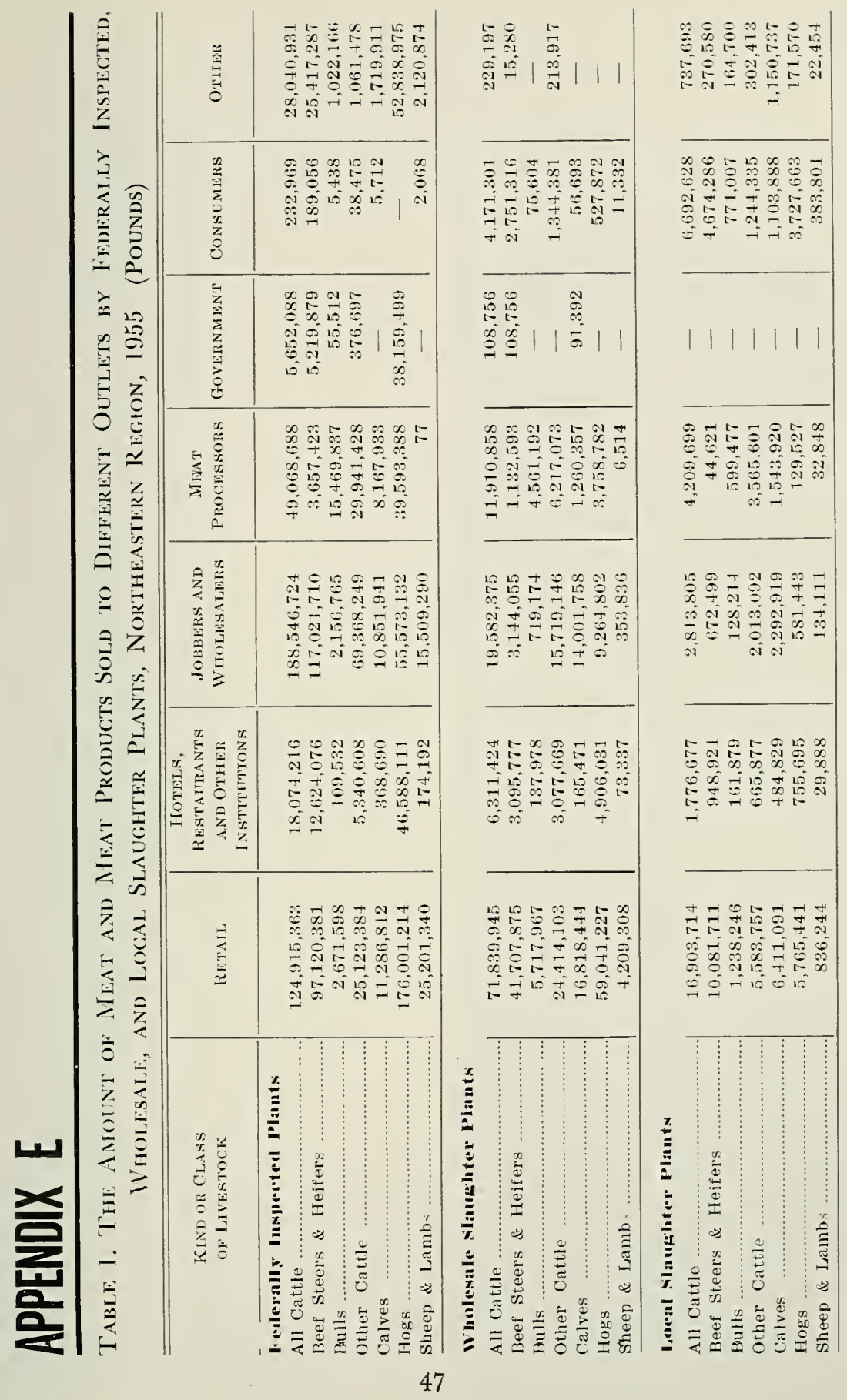




